
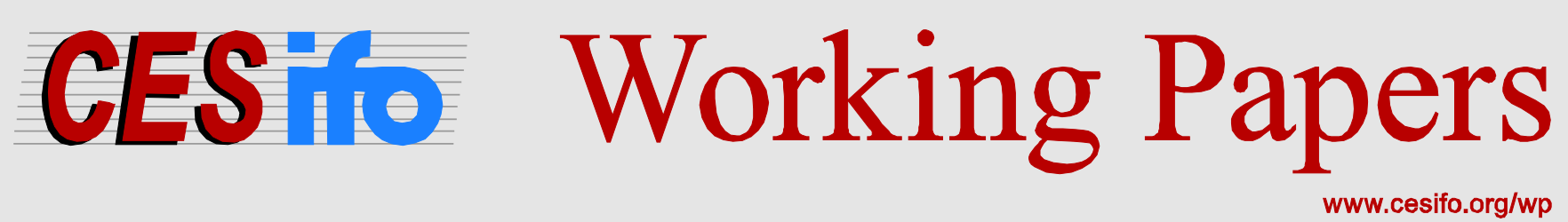

\title{
What Explains Sovereign Debt Litigation?
}

\author{
Julian Schumacher \\ Christoph Trebesch \\ Henrik Enderlein
}

\author{
CESIFO WORKING PAPER NO. 5319 \\ CATEgory 7: MONETARy POLICY AND InTERNATIONAL FinANCE \\ APRIL 2015
}
An electronic version of the paper may be downloaded
- from the SSRN website:
- from the RePEc website:
- from the CESifo website:
wWw.SSRN.com
www.RePEc.org
www.CESifo-group.org/wp




\title{
What Explains Sovereign Debt Litigation?
}

\begin{abstract}
We study the occurrence of holdout litigation in the context of sovereign defaults. The number of creditor lawsuits against foreign governments has strongly increased over the past decades, but there is a large variation across crisis events. Why are some defaults followed by a "run to the courthouse" and others not? What explains the general increase in lawsuits? We address these questions based on an economic model of litigation and a new dataset capturing the nearuniverse of cases filed against defaulting sovereigns. We find that creditors are more likely to litigate in large debt restructurings, when governments impose high losses ("haircuts"), and when the defaulting country is more vulnerable to litigation (open economies and those with a low legal capacity). We conclude that sovereign debt lawsuits can be predicted reasonably well with a simple framework from the law and economics literature.
\end{abstract}

JEL-Code: F340.

Keywords: sovereign debt, sovereign default, legal disputes, creditor lawsuits.

Julian Schumacher
Johannes Gutenberg University Mainz
Dpt. of Law, Management \& Economics
Jakob Welder-Weg 4
Germany - 55128 Mainz,
j.schumacher@uni-mainz.de

Henrik Enderlein

Political Economy

Hertie School of Governance

Friedrichstrasse 180

Germany - 10177 Berlin

enderlein@hertie-school.org

*corresponding author

This version: February 20, 2015

The authors gratefully acknowledge financial support from the German Research Foundation (DFG) under the Collaborative Research Centre 700. We also benefited from very helpful comments by Laura Alfaro, Charles Blitzer, Patrick Bolton, Chad Bown, Elias Brumm, Lee Buchheit, Russell Cooper, Till Cordes, Anna Gelpern, Mitu Gulati, Marcus Miller, Gernot Mueller, Carmen Reinhart, Felix Salmon, Martin Uribe, and Jeromin Zettelmeyer, as well as from participants at the ASSA Meeting in Philadelphia, the NBER Summer Institute (IFM), the EEA Conference in Gothenberg, the CEPR meeting in London, the Government Debt Crises Conference in Geneva, the ECB Global Sovereign Debt Workshop, the IPES meeting in Boston, the RES Annual Conference in London, and at seminars at Columbia University and at the Universities of Berlin, Bonn and Osnabrueck. We thank Inga Karrer, Said Khalid Scharaf, and Lilly Schoen for excellent research assistance. All remaining errors are our own. 


\section{Introduction}

On October 3, 2012, a subsidiary of the US hedge fund Elliott Associates succeeded in seizing the crown jewel of the Argentine navy in a Ghanaian port, the vessel ARA Libertad with 300 sailors on board. ${ }^{1}$ This drastic legal maneuver is just one of the many repercussions of the Argentinean default of 2001. Over the past decade, creditors have tried countless strategies to legally force Argentina to repay the debt it defaulted on. This paper is an attempt to better understand the occurrence of creditor litigation against sovereign debtors. We study situations in which banks or investment funds refuse to participate in a sovereign debt exchange offer and, instead, sue a defaulting government for full repayment in New York or London courts.

Legal disputes are now a standard ingredient of sovereign debt renegotiations, including the 2012 Greek debt exchange. ${ }^{2}$ It is also well-known that litigation can be costly and disruptive. Countries like Argentina devote substantial resources to defend against lawsuits and attachment attempts, despite the fact that sovereign assets are very difficult to seize. Moreover, litigious creditors can cause considerable externalities, such as a disruption of international trade flows, or by blocking government access to international capital markets (Sturzenegger and Zettelmeyer, 2006; Alfaro et al., 2010).

The rise of creditor litigation has triggered an international debate and many policy initiatives. Governments have advocated against litigious creditors ${ }^{3}$ and concerns about holdouts have motivated proposals on introducing collective action clauses (CACs) or a new bancruptcy regime such as the IMF's Sovereign Debt Restructuring Mechanism (SDRM) (see Rogoff and Zettelmeyer, 2002; IMF, 2003; Bolton, 2003). ${ }^{4}$ The European

\footnotetext{
${ }^{1}$ See Financial Times, October 3, 2012, "Argentine navy ship seized in asset fight".

2 "Fund threatens to sue over Greek bond losses", Financial Times, 15 December 2011; "Bet on Greek Bonds Paid Off for 'Vulture Fund"', New York Times, 15 May 2012; and "Slovak bank sues Greece over 2012 bond swap", Kathimerini, 9 May 2013.

${ }^{3}$ In a speech to the United Nations, the former UK finance minister Gordon Brown called creditor litigation by distressed debt funds "morally outrageous" (BBC, 10 May 2002), while Hank Paulson, his former US colleague, said that he "deplore[s] what the vulture funds are doing" (Bloomberg, 8 January 2008). The World Bank, the Paris Club, and the IMF, as well as NGOs such as Jubilee also warned of the dangers of holdout litigation (see Alfaro et al., 2010), and they have recently been joined by the European Commission (2012).

${ }^{4}$ Additional initiatives include a 2010 law passed in the UK to ban creditor lawsuits against the poorest countries undergoing debt relief. Two Channel Islands, Jersey and Guernsey, are currently preparing legislation that resembles the UK bill, while Belgium passed a bill to prevent the seizure of assets by litigious creditors in 2008. The African Development Bank has also recently set up the "African Legal Support facility" to support debtor countries facing litigation.
} 
debt crisis has revived the debate on litigation and related creditor coordination problems (see Gianviti et al., 2010; Roubini, 2010; Weder Di Mauro and Zettelmeyer, 2010; Tirole, 2012; Mody, 2013). Buchheit et al. (2013b), for example, argue that the threat of holdout litigation is a main explanation for the large scale bailouts of Eurozone countries. Because governments want to avoid a "messy" default as in Argentina, they may have become less prone to impose (high) haircuts on their private creditors. Also, the recent reports by the IMF (2013) and Buchheit et al. (2013a) suggest that creditor litigation has become a serious stumbling block for sovereign debt restructurings.

Others do not necessarily see creditor holdouts and litigation as a reason for concern. Shleifer (2003) and Scott (2006) argue that stronger creditor rights could have a positive effect on sovereign debt markets, because governments will be less likely to overborrow and default. ${ }^{5}$ A similar argument is made by Dooley (2000) and Pitchford and Wright (2007), who conclude that it can be welfare-reducing to make debt renegotiation less costly ex-post, e.g. by reducing holdout litigation. More generally, Bolton and Jeanne (2007) analyse the welfare effects of "easy" versus "hard" sovereign debt restructuring.

This study is motivated by the fact that there is only little empirical knowledge on the phenomenon of sovereign debt litigation and related creditor coordination problems, despite the many policy initiatives and a large body of related theoretical work. The existing literature has predominantly focused on a few high profile litigation cases, like Elliott v. Peru or Argentina, while systematic evidence has been missing.

Our analysis builds on a new dataset by Schumacher et al. (2014) that comes close to a census of all debt-crisis related lawsuits filed between 1978 and 2010 in the US and the UK, the two most relevant jurisdictions for international sovereign debt disputes. ${ }^{6}$ The data are hand-coded from electronic court records from the comprehensive PACER ${ }^{7}$ database as well as from documents from Lexis Nexis Law, Westlaw, Casetrack, Justis, and BAILII. Altogether, we evaluated more than 10,000 pages of legal documents and verified each data entry across all sources available, including previous data collections and

\footnotetext{
${ }^{5}$ Similarly, Fisch and Gentile (2004) suggest that holdout creditors can foster the functioning of credit markets in distress and thereby facilitate the restructuring process.

${ }^{6}$ Recent research confirms the continued dominance of English and New York law in cross-border bond and loan markets, see IMF (2002), Das et al. (2012), and Gulati and Scott (2012).

${ }^{7}$ Public Access to Court Electronic Records, http://www.pacer.gov.
} 
academic research. ${ }^{8}$ This coding approach allows us to tackle one of the main hurdles in quantitative legal research: sample selection bias. For the US, we are able to identify the universe of initiated lawsuits following a default or restructuring, including those that are settled out-of-court or those which remain unresolved. The data reveal new insights:

- Stylized Fact 1: The probability of litigation has strongly increased.

We find that the total number of lawsuits is only 121 (not counting multiple lawsuits by the same creditor), but more than half of these cases have been filed since the year 2000. The likelihood that a debt crisis is accompanied by creditor litigation has increased from less than $10 \%$ in the 1980s to more than $40 \%$ in recent years.

- Stylized fact 2: There is a large variation across debt crisis cases.

We find that some defaults trigger dozens of lawsuit in foreign courts, others none. Overall, litigation affected only 31 of the 174 sovereign debt restructurings with foreign banks and bondholders between 1978 and 2010 (18\% of all cases). Similarly, we find that only 26 debtor governments were affected, out of a total of 69 defaulters.

The aim of this paper is to rationalize the above stylized facts on litigation occurrence. Why are some debt crises followed by a veritable "run to the courthouse", while most cases see no litigation at all? Is it true that poorer countries are more likely to be sued, as often suggested in the policy debate? And what explains the general rise in litigation occurrence over the past decades? We address these questions with a standard model from the law and economics literature and by estimating probit and count models using litigation measures as our dependent variable. The resulting framework is a first attempt to develop an "early warning system" of creditor lawsuits in the context of sovereign defaults.

To guide the econometric analysis, we draw on an established framework on the economics of litigation that goes back to Coase (1960), Landes (1971) and Posner (1973) and is surveyed by Cooter and Rubinfeld (1989). The model predicts litigation to be determined (i) by the expected probability of winning a lawsuit (landmark judgments and changes in legal doctrine), (ii) by the cost of litigation to creditors and debtors, and (iii) by

\footnotetext{
${ }^{8}$ In particular, the cases identified in the HIPC initiative reports by the IMF and the World Bank (various issues), and those listed in Cleary Gottlieb Steen \& Hamilton and Clifford Chance (1992), Buchheit (1999), EMTA (2009), IIF (2009) and in the academic literature (Singh, 2003; Sturzenegger and Zettelmeyer, 2006; Alfaro et al., 2010; Trebesch, 2010).
} 
the scope of damage suffered by creditors. Moreover, we draw on theories from international finance and international trade disputes to further discipline our choice of explanatory variables. The seminal paper by Bulow and Rogoff (1989a) suggests that banks can impose legal sanctions on defaulting sovereigns and that the resulting asset seizures will disrupt international trade. If this is true, economies that are more open will be more vulnerable to litigation. We therefore include measures of trade and financial openness as a proxy for the creditor's probability of winning. We also account for the characteristics of each debt restructuring. First, we include the amount of restructured debt, as a proxy for the number of creditors. This is in line with the model by Pitchford and Wright (2012a), which predicts that more creditors increase negotiation delays and the probability of litigious holdouts. Second, we include the size of haircuts, which is in line with the related paper by Bi et al. (2011). High creditor losses make it more attractive to reject the exchange offer and instead sue for repayment of $100 \%$ of face value (see also Buchheit, 1999; Roubini and Setser, 2004). Finally, we control for the legal capacity of debtor governments, the cost of litigation to creditors, and for the existence of liquid secondary markets.

The results are in line with the theoretical priors. Landmark judgments are important in explaining the observed number of lawsuits. But legal factors become less relevant once we control for economic and financial variables. In particular, we find that trade openness, deal size (amounts restructured), and the scope of creditor losses ("haircuts") are economically and statistically significant predictors of creditor litigation after a sovereign default. A one standard deviation increase in haircut size or in the amount restructured more than doubles the probability of litigation (from $6 \%$ to more than $12 \%$ ). These findings are robust to including time fixed effects, restricting the sample to the 2000s, and excluding outliers (Argentina, Brazil, Peru). The results also hold when estimating IV regressions that account for the potential endogeneity of haircut size. We conclude that both legal and economic variables help to explain the occurrence and rise of sovereign debt litigation in the past decades.

Related literature: The paper contributes to the literature in several ways. First and foremost, we conduct the first broad-based empirical analysis on the occurrence of sovereign debt litigation, an issue that has received considerable attention in economic 
research. Many recent theory papers have analyzed creditor holdouts, litigation, and the legal framework of sovereign restructurings, including Miller and Zhang (2000), Ghosal and Miller (2003), Weinschelbaum and Wynne (2005), Gai et al. (2004), Haldane et al. (2005), Bolton and Jeanne (2007), Pitchford and Wright (2007, 2012a), Engelen and Lambsdorff (2009), Bi et al. (2011), Lanau (2011), and Ghosal and Thampanishvong (2013). Our paper differs from these contributions in that we use a modeling framework from law and economics which has proven successful in many fields, but has so far not been used to study litigation in sovereign debt markets. More importantly, we expand the empirical literature on creditor litigation, which has been lagging behind theory and remains scarce. Sturzenegger and Zettelmeyer (2006) summarize the history of sovereign debt law, Miller and Thomas (2007) analyze the Argentine litigation episode, Alfaro et al. (2010) and Bradley et al. (2010) test the impact of major court decisions on sovereign bond prices, while Schumacher et al. (2014) study the consequences of litigation on government access to capital markets, trade, and delays in crisis resolution. ${ }^{9}$ We are not aware of any previous paper that tests under which circumstances litigation is most likely to occur.

Second, we expand the literature on the general economics of litigation (e.g. Lanjouw and Lerner, 1997; Lerner, 2010). We are among the first to empirically analyze litigation in the context of financial distress and default. Methodologically, we avoid the "tip of the iceberg" problem, a central obstacle in the quantitative analysis of litigation (Priest and Klein, 1984). Researchers on litigation typically only observe cases brought to court, but not the underlying sample of harmful events, such as the total pool of car accidents. In contrast, we observe the full sample of sovereign debt restructurings that could potentially have resulted in legal action by using the data collections by Enderlein et al. (2012), Das et al. (2012), and Cruces and Trebesch (2013). This allows us to draw unbiased inference on the decision to litigate.

Third, we add to a literature on international economic disputes involving sovereign states. Many recent papers have studied trade litigation and related enforcement problems (e.g. the models by Maggi and Staiger, 2011, 2013; Beshkar, 2013). Unlike in the sovereign

\footnotetext{
${ }^{9}$ There are also dozens of legal studies on the implications of individual cases or on the development of legal doctrine in the field, e.g. Hurlock (1984a,b), Goldman (2000), Wheeler and Attaran (2003), Fisch and Gentile (2004), Gelpern (2005), Blackman and Mukhi (2010), Broomfield (2010), Waibel (2011), and many others.
} 
debt context, however, theory work in this field has been accompanied by a rich body of empirical papers on the determinants and effects of trade disputes, mostly using WTO data (e.g. Bown, 2004, 2005a,b; Busch and Reinhardt, 2006; Grinols and Perrelli, 2006; Davis and Bermeo, 2009). Here we exploit previously unavailable data to add empirical insights on sovereign debt litigation - an increasingly important type of cross-border disputes.

\section{Background and stylized facts}

This section describes the legal framework and characteristics of sovereign debt litigation over the past decades. We summarize insights from the legal literature and present stylized facts from our new database, which captures the near-universe of lawsuits filed by institutional investors in the US and the UK in the context of sovereign defaults and restructurings since 1978 (Schumacher et al., 2014). We focus on the period after 1978, since this is the year in which the UK implemented the State Immunity Act, which followed the US Foreign Sovereign Immunities Act (FSIA) of 1976. It was thus only in the late 1970s that sovereign debt lawsuits became possible in these two countries.

\subsection{Sovereign immunity and creditor litigation: past and present ${ }^{10}$}

Historically, private creditors had no legal device to force foreign governments to repay in the event of a default. Unlike corporations, governments cannot be liquidated and sovereign debt is typically not backed by collateral. In addition, debtor governments were protected from litigation and asset seizures by the doctrine of "absolute" sovereign immunity, which states that a government cannot be sued in foreign courts.

Since the 1950s, however, sovereign immunity has eroded and lawsuits against defaulting governments in foreign jurisdictions have become possible (Weidemaier, 2014). In the second half of the 1970s, however, both the US and the UK implemented the above mentioned legislation that allowed private individuals to take foreign governments to court over commercial disputes. These reforms opened the gate for today's era of sovereign debt litigation, which was shaped by four main court decisions.

\footnotetext{
${ }^{10}$ This section is largely based on Fisch and Gentile (2004), Sturzenegger and Zettelmeyer (2006), Foster (2008), Alfaro et al. (2010), Blackman and Mukhi (2010), Waibel (2011), and Weidemaier (2014). Parts are also taken from Schumacher et al. (2014), who provide a more detailed overview.
} 
The first benchmark case on sovereign debt litigation was Allied Bank v. Costa Rica ${ }^{11}$ in 1982, when a group of banks went to court in the US after refusing to accept a haircut in Costa Rica's debt restructuring. The New York court granted a ruling in favor of Allied and established that Costa Rican government assets could in principle be subject to attachment in the US. The case significantly weakened the classic debtor defense of sovereign immunity, as well as further prominent defenses such as the act of state doctrine and the principle of international comity (see Sturzenegger and Zettelmeyer, 2006).

A second landmark decision was Weltover $v$. Republic of Argentina ${ }^{12}$ in 1992, when the US Supreme Court interpreted the issuance of external sovereign debt as a commercial activity. This decision was fundamental, since it effectively granted US courts jurisdiction over sovereign debt issued under US governing law. Three years later, CIBC v. Banco Central do Brazil ${ }^{13}$ achieved the first major litigation success by a professional distressed debt investor. The fund owned by the Dart family acquired USD 1.4 bn of Brazilian debt, refused to participate in Brazil's Brady deal of 1992, received a favorable judgment in court, and then sold the debt again at a substantial profit. The case demonstrated the possibly large rewards of holdout litigation. It also weakened the so called champerty defense, which prohibited the purchase of debt with the primary intent of filing a lawsuit. The demise of champerty set the stage for litigation by distressed debt funds, which buy debt at depressed prices in the secondary market and then sue for full repayment in court. Our data show that hedge funds are now the dominant player in this market, accounting for more than $75 \%$ of lawsuits filed since 2000 .

Elliott v. Peru ${ }^{14}$ in 2000 marks a fourth landmark decision in this field of law. The case is in many ways representative for the past two decades of sovereign litigation, which can be described as a "hunt for assets". The main challenge for litigious creditors today is not to achieve a favorable judgment, but to execute it and to collect assets. This is because US law only allows attachments on government property that is both located in the United States and used for commercial purposes. ${ }^{15}$ In the lawsuit against Peru, Elliott argued that the pari passu clause forces Peru to pay all creditors on an equal basis, including holdout

\footnotetext{
${ }^{11}$ Allied Bank International v. Banco Credito Agricola de Cartago, 757 F.2d 516.

${ }^{12}$ Republic of Argentina v. Weltover, Inc, 504 U.S. 607.

${ }^{13}$ CIBC Bank and Trust Co. (Cayman) Ltd. v. Banco Central do Brasil, 886 F. Supp. 1105.

${ }^{14}$ Elliott Associates L.P., General Docket No. 2000/QR192 (Ct. App. of Brussels)

${ }^{15}$ Similar constraints apply in the UK, France, or Germany (Foster, 2008).
} 
creditors who refused to participate in a past restructuring. Based on this strategy, Elliott succeeded in blocking an interest payment on Peru's Brady bonds. To avoid a default, Peru then quickly settled at face value. The same pari passu interpretation has been invoked in numerous other cases, most notably in 2011 by a subsidiary of Elliott which eventually led to Argentina's 2014 default. ${ }^{16}$ As of early 2015, however, no other plaintiff has succeeded in blocking interest or principal debt payments on sovereign bonds. ${ }^{17}$

The challenge of enforcing sovereign debt judgments has led distressed debt funds to attempt a variety of attachment strategies - including on assets such as government airplanes, oil tankers, export revenues, or central bank assets and social security funds in overseas accounts. Many of these seizure attempts are primarily aimed at disrupting a country's trade and capital flows, so as to increase the pressure on governments to negotiate a favorable out of court settlement.

Besides these spillover costs, governments and creditors are also faced with direct legal fees. While systematic data on the cost of litigation is missing, anecdotal evidence suggests that they can be very high. ${ }^{18}$ In the context of the 2006 Iraq restructuring, which involved large-scale litigation, the government paid reportedly USD $6.5 \mathrm{~m}$ in fees to its legal advisor, ${ }^{19}$ while Greece is said to have paid USD $8.5 \mathrm{~m}$ for legal counsel in the context of the 2012 debt restructuring, including for advice against holdouts and litigation. ${ }^{20}$ Even higher fees are reported for Argentina, which is estimated to have paid about USD 400m for its defense. ${ }^{21}$ On the creditor side, the hedge fund Elliott claims to have paid "tens of millions of in legal fees" to sue Argentina over the past 12 years, ${ }^{22}$ initiating "over 900 seizure attempts over Argentine assets". ${ }^{23}$ Similarly, the investment fund FG Hemisphere claims to have spent USD 20m in its legal dispute with the Democratic Republic of Congo

\footnotetext{
${ }^{16}$ NML Capital, Ltd. v. Republic of Argentina, 08 Civ. 6978 (S.D.N.Y.)

${ }^{17}$ Another recent case based on pari passu, led by Export-Import Bank of China v. Grenada, 13 Civ. 1450 (S.D.N.Y.), was settled in January 2015 before a similar injunction had been made ("Grenada cuts loan deal with Taiwan", International Financing Review, 7 January 2015).

${ }^{18}$ Pitchford and Wright (2012a) provide a detailed overview on the cost of sovereign debt renegotiations, including legal expenses.

19 "Cleary Plays Key Role in Easing Iraq's Private Debt", New York Law Journal, 14 April 2006.

20 "Greece Discloses Fees Paid to Cleary During Sovereign Debt Crisis", The American Lawyer Daily, 22 March 2012; "Greece Details Payments to Advisers Used in Debt Restructuring", Bloomberg Business, 22 March 2012.

21 "Buitres: el país gastó en abogados unos USD 400 millones", La Nacion, 2 November 2014.

22 "Last Tango in Buenos Aires", Times Magazine, 14 August 2014.

23 "Argentina and hedge fund NML Capital ratify their commitment to keep fighting", Mercopress, 6 November 2014.
} 
(Brown Rudnick, 2012).

\subsection{Stylized facts: a puzzling variation across crises}

Figure 1 shows the evolution of sovereign debt litigation 1978-2010, in two ways. First, by counting the total number of cases pending in each year (left axis). ${ }^{24}$ This data series is obviously influenced by individual crises, in particular the large number of cases filed against Argentina. We therefore also match the litigation cases to the related debt crisis events and show the share of restructurings affected, i.e. the subset of restructurings which involved at least one sovereign debt lawsuit (as five year moving average, right axis). Both ways to cut the data confirm that the prevalence of litigation has strongly increased since the 1980s.

A further key insight from the data is the large variation across crises, as shown in Table 6 . Only $18 \%$ of restructuring events since 1978 were affected by litigation. The majority of crises involve only a single lawsuit, while others are followed by a veritable 'run to the courthouse'. Argentina faced lawsuits by 41 institutional creditors after its 2001 default, as well as dozens of suits by retail investors (which are not considered here). ${ }^{25}$ Other restructurings with large-scale litigation were Peru's Brady debt exchange, which triggered 13 lawsuits in the US, as well as Iraq 2006, Liberia 2009 and Congo 2007, which involved 10, 9 and 7 cases, respectively. Generally, we find that most cases are filed against middle-income countries in the emerging market world, albeit a third of all cases targeted highly indebted poor countries (HIPCs).

What explains the startling variation in litigation across restructuring events? Before conducting our own analysis below, we review the existing literature in search for explanations. We find no systematic study on the drivers of sovereign debt litigation, but various hints:

- A study on sovereign debt litigation by the financial sector groups IIF and EMTA emphasizes that investors will be likely to agree to a restructuring if the offer contains "mutually acceptable terms". Litigation is supposedly least likely in "cooperative

\footnotetext{
${ }^{24}$ We merge multiple suits by the same creditor against the same country into one observation, so that the data are structured in creditor-debtor conflict pairs.

${ }^{25}$ Retail investors typically sue for small amounts and are typically not successful in achieving favorable settlements (or in attaching assets).
} 
agreements performed in good faith" that are considered as "fair by the parties involved" (IIF, 2009, p. 3). This suggests that unilateral defaults with high haircuts may be more prone to litigation. Similarly, engaging in talks with a representative creditor committee is regarded as helpful to prevent legal disputes.

- In her proposal for an SDRM, Anne Krueger (2002) famously suggests that "the increasingly diverse and diffuse creditor community poses coordination and collective action problems" in sovereign debt restructurings, including litigation. Restructurings with a large number of diverse creditors could therefore be more affected by litigation.

- Moreover, in a memorandum to the IMF, Buchheit (1999) explains that litigious creditors partly select their "target" country based on the following criteria: (i) it must be easy to purchase and sell the country's debt on secondary markets, (ii) the debt must be in default and available at a deep discount, and (iii) the restructuring must involve debt issued under New York or English law, or in other ways be potentially subject to jurisdiction in New York or England.

Neither of these propositions, however, has been tested or brought to the data. We therefore have only limited empirical knowledge on what drives sovereign debt litigation. The next sections will try to shed new light on the issue.

\section{Theoretical framework and hypotheses}

This section proposes a theoretical framework to structure our empirical analysis. We start with a standard litigation model as reviewed by Cooter and Rubinfeld (1989) and Spier (2007) but apply it to the context of sovereign default and restructurings. The central trade-off in this framework is that creditors will only start a lawsuit if the expected value of going to court exceeds the expected value of not doing so. ${ }^{26}$ More specifically, we view a creditor's decision to file suit as a function of three terms: First, the full value of the claim in case she wins the case, multiplied by the expected probability of success. Second, the recovery value that she will be left with if she loses, multiplied by the expected

\footnotetext{
${ }^{26}$ Coase (1960) famously suggested that a conflict between two negotiating parties is most likely to result in a private settlement instead of a lawsuit in order to avoid the unnecessary costs of a legal battle. This assertion is reflected in sovereign debt markets as well: Most debt exchange offers achieve creditor participation of more than $90 \%$ (see Das et al., 2012).
} 
probability of losing. And third, the costs associated with conducting a trial, which occur independently from the trial's outcome. Since the government can influence this trade-off by setting the terms of the restructuring offer, our model consists of a single period two-stage game, which we solve by backward induction.

Suppose the government owes debt to external creditors and for some exogenous reason, e.g. a negative income shock, it decides to fully default or restructure this debt. This implies an exchange offer on the entire stock of outstanding debt, which is reduced by a haircut $h \in[0,1]$. A government has some discretion in its choice of $h$, but it is also subject to external pressure, in particular if it has requested official sector bailout money, which is the case in the vast majority of debt crises (Marchesi, 2003). The IMF and the Paris Club, for example, can demand a minimum haircut on commercial creditors to reduce the risk of a future default and to assure fair burden-sharing between the private and the official sector (Erce, 2013). We thus assume that the overall haircut $h$ has two components: first, an exogenous part $h_{e}$, which is determined by ability-to-pay constraints and external pressure. Second, an endogenous component $\delta \in\left[0,1-h_{e}\right]$, which is freely chosen by the government and can be interpreted as the willingness-to-pay variable. The lower $\delta$, the more "creditor friendly" the offer, so that the overall haircut is given by $h=h_{e}+\delta$.

The government faces a trade-off when it decides about $\delta$ : increasing the haircut reduces the payment to the creditors who accept the restructuring, but at the same time induces more investors to litigate by reducing the recovery value. If the government cannot find a haircut which allows repayment out of its available resources, it will go into full default, without any repayments to foreign creditors. This outside option implies that an increase in the creditors' legal rights can become detrimental if too many choose to hold out and litigate instead of accepting the offer.

Importantly, we assume that the government cannot discriminate among creditors. The haircut offer $h$ is identical for all investors. This implies that the universal (one-size-fits-all) offer can trigger different reactions among heterogeneous creditors.

\subsection{Creditor decision}

The market consists of $n$ creditors, each of which holds an identical claim against the government equal to $d$, such that the aggregate debt the government owes is given by 
$D=n d$. Creditors are heterogeneous in the costs they face when going to court. For instance, highly specialized distressed investors are more experienced in suing debtor governments and in locating attachable assets and could thus face lower costs of litigating (rejecting the offer). We therefore denote creditor litigation costs $c$ with a subscript $i$, where each $c_{i}$ is a realization of $c \in[0, \bar{c}] . f(c)$ and $F(c)$ describe the density and cumulative distribution functions of $c$, respectively. We assume that $f^{\prime}(c)>0$ in order to describe a cost distribution with fewer creditors with low costs of litigating than creditors with high costs. This is in line with the relatively limited number of creditors engaging in litigation that we observe in the data. ${ }^{27}$

After receiving the restructuring offer, creditors decide whether to accept or not. Accepting implies that the debt claim is reduced by the size of the haircut to $(1-h) d$. This claim will be paid out for sure. The alternative choice is to reject the offer and go to court to demand full repayment. This litigation decision is denoted by a binary variable $L_{i}=\{0,1\}$, where $L=0$ if the creditor participates in the restructuring and $L=1$ if she litigates instead.

Litigating is risky, because the full claim will only be recovered with success probability $p \in[0,1]$. The lawsuit will thus fail with probability $(1-p)$, in which case the creditor receives nothing. As in Spier (2007), we assume that the plaintiff's probability of winning $p$ increases in the opportunity cost of the defendant. In the sovereign debt context, one can think of $p$ as a function of the strength of creditor rights at the time of default $l_{t}$, and the government's cost of facing litigation, denoted as $c_{g}$, so that $p \equiv p\left(l_{t}, c_{g}\right)$, with $\frac{\partial p}{\partial l_{t}}>0$ and $\frac{\partial p}{\partial c_{g}}>0$. We assume that both $l_{t}$ and $c_{g}$ are exogenously given. Government costs will arise due to legal fees but also due to litigation externalities such as the cost of losing access to international capital markets or due to asset seizures abroad. Changes in legal doctrine also play a crucial role. As we discuss above, landmark judgments have strengthened creditor rights since the 1980s, thus pushing up $l_{t}$.

Creditors maximize profits subject to a budget constraint. Their profits consist of income from the recovery value of defaulted government debt if they participate in the

\footnotetext{
${ }^{27}$ We do not make a specific assumption about the cost distribution in order to keep the analysis general. However, it is reasonable to think about the distribution of litigation costs as having a small mass of creditors with low costs, and a relatively large mass with high costs. An example would be a beta distribution with parameter specification $\alpha>\beta$.
} 
restructuring, $(1-h) d$, and cash savings, $s_{i}$. Creditors will thus invest their full endowment $w_{i}$ into savings or into expenses for litigation $c_{i}$, so that:

$$
\begin{aligned}
\max _{L_{i}} & \Pi_{i}=s_{i}+L_{i}(p d)+\left(1-L_{i}\right)(1-h) d \\
\text { s.t. } & w_{i}=s_{i}+L_{i} c_{i}
\end{aligned}
$$

Combining objective and constraint yields $\Pi_{i}=w_{i}+L_{i}\left(p d-c_{i}\right)+\left(1-L_{i}\right)(1-h) d$. Hence, the individual expected value of litigating is $p d-c_{i}$. Creditor $i$ will only choose $L_{i}=1$ and litigate if this expected value exceeds the return of accepting the exchange offer, $(1-h) d$ :

$$
p d-c_{i} \geq(1-h) d
$$

Conditional on $h$ and $p$, there can be a creditor for which eq. (2) holds with equality. This marginal creditor $i^{*}$ is indifferent between litigating and accepting the haircut so that:

$$
c_{i}^{*}=(p-(1-h)) d
$$

The intuition is that for this marginal creditor, the probability of winning has to exactly offset the loss from accepting the offer, so that she is indifferent between her two options.

In case $c_{i}^{*}<0$, it is not optimal for any existing creditor to file suit, resulting in full participation. However, if there is a $c_{i}^{*} \geq 0$ such that eq. (3) is fulfilled, there will be a non-negative share of litigating creditors. This creditor group, with costs smaller than the marginal creditor $i^{*}$, is equal to $\operatorname{Prob}\left(c_{i} \leq c_{i}^{*}\right)=F\left(c_{i}^{*}\right) \equiv \Phi$. Put differently, $\Phi$ is the share of creditors that will reject the restructuring offer and litigate instead, while $(1-\Phi)=\operatorname{Prol}$ is the share of creditors that accept the haircut. We denote the density at the marginal creditor $f\left(c_{i}^{*}\right)$ as $\varphi$.

\subsection{Government decision}

The government can choose to offer a debt restructuring with a haircut $h$ and receive its income less repayments, $V^{R}$, or go into full default and refuse any payments to its creditors (this is equivalent to the government's problem in Bolton and Jeanne, 2007, 2009). Going into full default represents the government's outside option with value $V^{F D}$. If the 
government chooses this option, creditors receive nothing. The outside option presents essentially a participation constraint limiting the government's willingness to repay more than its available resources (see e.g. Aguiar and Amador, 2013; Sandleris, 2012, for a detailed exposition of such a framework). The government's payoff is given by:

$$
V=\max \left\{V^{R}, V^{F D}\right\}
$$

We normalize $V^{F D}=0$ for simplicity, although assuming a different autarky payoff does not affect the results. If the government chooses to make an exchange offer, it can anticipate the creditors' reaction to the haircut $h$. Moreover, we follow previous work and assume that a default causes an additional output cost $\kappa$, which increases in the magnitude of the discretionary haircut, $\kappa^{\prime}(\delta)>0, \kappa^{\prime \prime}(\delta)>0$ (a similar assumption is made e.g. by Calvo, 1988; Bolton and Jeanne, 2007; Bi et al., 2011). This additional output cost can be thought of as other costs of default considered in the literature, for example reputational costs, trade sanctions, or damages to the domestic banking system. The government's payoff from offering a restructuring is thus given by:

$$
\begin{aligned}
V^{R} & =\max _{\delta} y-D(\underbrace{\int_{0}^{c_{i}^{*}} f(c) p d c}_{\text {Repayment to holdouts }}-\underbrace{\int_{0}^{c_{i}^{*}} f(c) c_{g} d c}_{\text {Gov't cost of litigation }}-\underbrace{\int_{c_{i}^{*}}^{\bar{c}} f(c)(1-h) d c}_{\text {Repayment to participants }})-\kappa(\delta) \\
& =\quad y-D\left(\Phi\left(p+c_{g}\right)+(1-\Phi)(1-h)\right)-\kappa(\delta)
\end{aligned}
$$

where $y \in\left[y_{L}, y_{H}\right]$ denotes the government's uncertain exogenous income. The government will choose to make a restructuring offer as long as the sum of the second and third term in (5), the expected repayments and additional costs, do not exceed the realized income. Let $\bar{y}$ denote the income equal to these costs of a restructuring offer. Then the probability of full default is given by the probability that $y \leq \bar{y}$, which can be written as $\pi=\int^{\bar{y}} f(y) d y$. An implication of the full default outside option is that a change in the variables increasing the expected repayments is beneficial for investors only as long as the government does not go into full default. But an increase in the expected repayments also increases the probability $\pi$. For instance, stronger legal creditor rights may increase the probability of successful litigation $p$, and thus raise expected repayments. However, this can also lead to 
a higher $\pi$ by making an inorderly full default more attractive than a debt exchange whose costs could exceed the government's resources.

Empirically, the latter case is an unlikely situation. In our sample period, all defaulting countries restructured their debt rather than going into complete autarky. We are therefore more concerned with predictions about the share of creditors litigating, conditional on a debt restructuring.

In designing the terms of a debt exchange, the government can anticipate the share of litigating investors. Maximizing $V^{R}$ with respect to $\delta$ yields the first order condition as:

$$
\Gamma \equiv \frac{\partial V^{R}}{\partial \delta}=D\left(\varphi d\left(1-h-p-c_{g}\right)-(1-\Phi)\right)-\kappa^{\prime}(\delta)
$$

This simple setup helps rationalizing the occurrence of creditor litigation in sovereign debt restructurings, especially when complemented with insights from the international finance literature. The comparative statics on $\Phi$ from (6) lead us to three testable hypotheses about the share of litigation, which are presented in the next section. ${ }^{28}$

\subsection{Hypotheses}

First, we expect an increase in $p$ to increase the likelihood of litigation.

$H 1: \quad \frac{\partial \Phi}{\partial p}>0$. The higher the creditor probability of winning a lawsuit (or favorable settlement), the higher the risk of litigation.

As explained above, we think of the probability of winning as a function of the legal environment $l_{t}$ and the government's cost of litigation $c_{g}$. We control for the legal environment by including variables capturing the effect of the four benchmark decisions outlined in section 2. Our main proxy for $c_{g}$ is the openness of the debtor economy, which is motivated by the seminal paper by Bulow and Rogoff (1989a). Their model assumes that creditors can impose legal sanctions on a defaulting country by "seizing" a portion of its exports and lowering its gains from trade (see also Rose, 2005; Mendoza and Yue, 2012). In line with this argument, we expect open economies to be particularly vulnerable to the disruptive effects of debt litigation on trade and capital flows. As an additional proxy for sovereign litigation costs, we use a measure of legal capacity. We expect a poor, developing country

\footnotetext{
${ }^{28}$ See the appendix for a derivation of the comparative statics.
} 
to be ill-prepared for a protracted legal dispute in New York or London, and also to be less able to shield its assets from attachment by experienced distressed investors. This intuition is in line with Davis and Bermeo (2009), who argue that developing countries face high fixed costs in WTO disputes, as well as Maggi and Staiger (2013) and Busch and Reinhardt (2003), who find that poorer countries tend to settle their trade disputes earlier and are also less successful in extracting concessions. Accordingly, we expect an increase in debtor legal capacity to lower $c_{g}$ and thereby $p$, resulting in less litigation.

Second, we focus on those parameters that vary across debt crises, in particular the haircut and the scope of the restructuring $D$.

$H 2: \quad \frac{\partial \Phi}{\partial h_{e}}>0, \quad \frac{\partial \Phi}{\partial D}>0$. Higher exogenous haircuts and larger restructurings increase the risk of litigation.

It is intuitive that a higher haircut increases the incentives to reject an exchange offer and litigate for full repayment, i.e. for $100 \%$ of face value. The higher the haircut, the lower the break-even cost of going to court. A similar rationale applies when investors buy defaulted debt on the secondary market, because the wedge between face value and market value of traded debt is likely to increase in the (expected) haircut on that debt. In line with Bi et al. (2011), we therefore expect a higher haircut to increase litigation occurrence. Since the endogenous haircut is the choice variable of the government, in the empirical analysis we will allow haircuts to be both exogenously and endogenously determined.

Furthermore, we expect larger debt restructurings to be more affected by litigation. One reason is that larger restructurings typically affect a larger number of creditors. ${ }^{29}$ More creditors make coordination more difficult and increase the probability that at least some creditors hold out and litigate. This simple rationale is consistent with the model of Pitchford and Wright (2012a,b), which predicts that a higher number of creditors results in longer delay in sovereign debt renegotiation. Another potential reason why larger deals involve more litigation are economies of scale. To see this, recall that we have assumed a fixed cost of litigation for creditors, meaning that $c_{i}$ is independent of the size of debt involved. A larger $D$ will then translate into a higher share of litigating creditors because

\footnotetext{
${ }^{29}$ Trebesch (2010) codes the number of creditors for a sample of 90 sovereign bank debt exchanges in the "London Club" era, i.e. between 1980 and 1997. He finds a close relationship between deal size (amount restructured in USD) and the number of banks affected by the exchange (the correlation coefficient is 0.46).
} 
the ratio of cost to potential return (full repayment of $d$ ) decreases.

Third, we expect litigation to decrease in $\bar{c}$.

$H 3: \quad \frac{\partial \Phi}{\partial \bar{c}}<0$. Higher legal costs for creditors decrease the risk of litigation.

To account for this, it is useful to think of $c_{i}$ as the opportunity costs of holding out. When credit is cheap for all investors (and the distribution of creditor costs bound by a low $\bar{c}$ ), it is less costly to buy and hold non-performing debt for litigious purposes. In contrast, holdout litigation is a costly activity in times of high borrowing cost (high $\bar{c}$ ), such as the high-yield period of the 1980s.

In the next section, we bring these theoretical predictions to the data.

\section{Empirical approach and results}

\subsection{Estimation strategy and data}

Empirically, we do not observe the marginal creditor's cost $c_{i}^{*}$. However, we do observe the actual occurrence of litigation in debt restructurings, $Y$. For this purpose, we use the full list of sovereign restructuring events between 1978 and 2010 from Cruces and Trebesch (2013), and match it with our dataset on litigation events, accounting for lawsuits filed either before or after the respective debt exchange. This leaves us with a cross-section of 174 restructuring events, of which 31 involved creditor litigation. ${ }^{30}$

As a baseline we estimate the probability of a restructuring being affected by legal disputes. Put differently, we are looking for debt crises in which $c_{i}^{*} \geq 0$, so that the marginal creditor's cost of litigation is within the bounds of $c$ (non-negative), resulting in at least one lawsuit. Translated into a standard latent variable model, this implies that

$$
Y= \begin{cases}1 & \text { if } c_{i}^{*} \geq 0 \\ 0 & \text { if } c_{i}^{*}<0\end{cases}
$$

\footnotetext{
${ }^{30}$ The original dataset by Cruces and Trebesch (2013) listed 180 debt exchanges. We use their recently updated version, which includes four previously omitted cases (Congo 1988, Mozambique 2007, Nicaragua 2007 and Liberia 2009,) and drops two deals which turned out to not have been implemented (Mozambique 1987 and Cameroon 2002). Note also that a few countries saw two debt restructurings in the same year. In case the court documents do not allows us to uniquely match a litigation case to one of the two events, we merge them into one observation per country and year. This yields a final sample of 174 cases.
} 
where $Y$ switches from 0 to 1 if one or more creditors file suit in London or New York. We thus estimate the following reduced-form model:

$$
\begin{aligned}
& \operatorname{Prob}(Y=1 \mid \mathbf{X})= \\
& \Phi(\underbrace{\beta_{1} \text { Landmark Judgments }}_{\text {Legal Environment }}+\underbrace{\beta_{2} \text { Trade Openness }+\beta_{3} \text { Legal Capacity }}_{\text {Debtor Costs }} \\
& +\underbrace{\beta_{4} \text { Haircut }+\beta_{5} \text { Debt Amount }+\beta_{6} \text { Bond Exchange }}_{\text {Restructuring Characteristics }}+\underbrace{\beta_{7} \text { Borrowing Costs }}_{\text {Creditor Costs }} \\
& +\underbrace{\beta_{8} \text { GDP per capita }+\beta_{9} \text { Sec. Market }+\beta_{10} \text { Share US } / \text { UK debt }}_{\text {Controls }})
\end{aligned}
$$

In our main model we use a dummy on litigation occurrence as dependent variable, because this approach is least likely to suffer from measurement error. However, we also propose two alternative approaches. First, we show results of a count model that uses the number of lawsuits filed as dependent variable. For this purpose, we assume $Y$ to follow a mixed Poisson-gamma (negative binomial) distribution, since the number of cases per debt crisis is naturally restricted to positive integers (Cameron and Trivedi, 1986). ${ }^{31} \mathrm{In}$ addition, we compute the debt under litigation as a share of total restructured debt (in $\%)$ and use this "share litigated" as our dependent variable. Specifically, we estimate a generalized linear model with a probit link function, a method best suited for fractional dependent variables that vary between 0 and 1 . Unfortunately, the data on the number of litigating creditors and on litigation amounts are noisy, so that the results from these two alternative models should be taken with care. ${ }^{32}$

Methodologically, a further important step is to account for the possibility that haircut size is endogenous in our model. We do so by instrumenting the haircut measure with the country's debt/GDP ratio in the year prior to the restructuring. With a view to our model, debt/GDP can be thought of as an ability-to-pay variable that exogenously determines a part of the government's offered haircut. More formally, our exclusion restriction is that

\footnotetext{
${ }^{31}$ We consider likelihood ratio tests, AIC statistics, and Vuong test results for model selection between the negative binomial model, the Poisson model, and variants accommodating zero-inflation.

${ }^{32}$ We do not have information on amounts for $24 \%$ of the lawsuits, resulting in a downward bias in this measure. Also, the number of lawsuits can be biased upwards or downwards. Multiple creditors can unite behind one lawsuit (e.g. Allied v. Costa Rica), while in other cases the same creditors can file multiple actions under different names and we cannot always identify these instances.
} 
the level of indebtedness will only affect creditor litigation through its effect on haircut size (after controlling for the amount restructured, and per capita GDP). As we confirm below, we find that the debt/GDP ratio is an important determinant of haircut size, but not significantly correlated with litigation occurrence.

The ordering of the explanatory variables follows our theoretical discussion above. As before, we start with proxies for $p$, the creditor's expected probability of winning, in particular measures for the legal environment and the cost of litigation for debtor countries. To account for changes in legal doctrine, we follow a similar approach as Bradley et al. (2010) and use time dummies on particularly important landmark judgments and their aftermath. The first dummy captures the period after the first significant sovereign litigation case Allied Bank v. Costa Rica, and takes the value 1 for each year between 1985 and 1991. The second indicator captures the time after Weltover $v$. Argentina (1992-1994), a decision that paved the way for US-based creditor litigation. The third dummy covers 1995-1999, the period after CIBC v. Brazil, which was the first major "vulture" success against a defaulting sovereign. Finally, we include a dummy for the year 2000 onwards, when Elliott $v$. Peru set a precedent on how judgments could actually be enforced. Our reference category is the time pre-1985, which means that we expect the coefficient of each dummy to be positive. To proxy for debtor litigation cost, we include measures of trade openness, in particular (Imports+Exports)/GDP, for which we use data from the World Bank and the IMF Direction of Trade Statistics. In addition, we measure financial openness based on Lane and Milesi-Ferretti (2007) and compute (Foreign Assets+Foreign Liabilities)/GDP. With a view to the above, we expect more open economies to be more prone to litigation. The same is true for those debtor countries with a weak bureaucratic and legal capacity. To proxy for legal capacity, we draw on a standard measure from the World Bank Governance Indicators (Kaufmann et al., 2010), because there is no cross-country measure of actual legal capacity. Specifically, we use the "Government Effectiveness" subindicator, which captures the sophistication of a country's public administration and its institutional and bureaucratic effectiveness. ${ }^{33}$

The second set of explanatory variables vary across debt restructurings, in particular

\footnotetext{
${ }^{33}$ For reasons of data availability and to reduce potential endogeneity, we use average government effectiveness over the entire sample period.
} 
proxies for $h$ and $D$. We rely on the data on haircuts (creditor losses) and restructuring amounts as coded by Cruces and Trebesch (2013) for all deals since the 1970s. In our benchmark regressions, we use the present value (PV) haircut estimates where $h=1-\frac{P V_{\text {new }}}{P V_{\text {old }}}$, but the results are very similar when using haircuts in face value terms (reduction in principal). The amount of debt restructured is computed in real 2005 USD. In line with the arguments outlined above, we expect larger restructurings and those with higher haircuts to trigger more litigation. Figure 2 provides preliminary indication that this is indeed the case. For completeness, we also include a dummy indicating whether the restructuring involved sovereign bonds, as opposed to deals that only involved bank debt. In line with the literature on creditor coordination problems, we expect bond exchanges to affect a more dispersed creditor population, resulting in more holdouts.

Third, we introduce a proxy for creditor litigation costs. We use Barclays' US Corporate High Yield Bond Index, a measure of corporate borrowing costs which goes back to the late 1970s. Since higher borrowing costs decrease the returns to litigation, we expect a negative relationship between this yield index and the probability of lawsuits.

Finally, we aim to account for additional heterogeneity across countries and default cases. First, we include per capita GDP in $1980{ }^{34}$ Second, we construct a dummy variable for the presence of secondary market debt trading. It takes the value 1 if a country's sovereign bonds or loans are actively traded on secondary markets. ${ }^{35}$ However, the role of secondary markets trading in our context is not straightforward. Buchheit (1999) argues that liquid secondary markets make it easier for specialized investors to buy defaulted bonds and then litigate for full repayment. In contrast, Pitchford and Wright (2010) show that the effects of secondary markets on debt renegotiation are ambiguous. The impact of secondary market trading is therefore an empirical question. As a last control, we account for the legal characteristics of a country's sovereign debt portfolio, by measuring the share of outstanding external debt that was issued under either US/New York or English law.

\footnotetext{
${ }^{34}$ We use beginning-of-sample values instead of time-varying GDP data in order to avoid endogenous effects of debt crises on GDP. The results, however, are robust to using yearly lags of GDP per capita.

${ }^{35}$ For the 1990s and 2000s we check whether a country's bonds are included in the JP Morgan Emerging Market Bond Index, which was launched in 1993 and only includes debt instruments that meet a range of liquidity conditions. For the late 1980s and early 1990s we account for secondary market trading of sovereign loans using data by Sawada (2001). The data show that during the 1980 s only $15 \%$ of the countries in our sample had a liquid debt market. This number rises to over $40 \%$ for restructurings during the 1990 s and 2000 s.
} 
We construct this measure from Dealogic whenever possible, using the information on the legal characteristics of more than 20,000 sovereign bonds and loans issued in international primary markets. ${ }^{36}$ In line with Buchheit (1999), we expect a higher ratio of US or English law debt to increase the probability of litigation in US and UK courts. Table 1 provides an overview of all variables used in the analysis, their sources, as well as their respective summary statistics.

\subsection{Main results}

Table 2 reports our main results, displayed as average marginal effects. All main explanatory variables have the expected sign. Landmark judgments are clearly significant, with a large quantitative effect on the propensity of litigation (column 1). This finding is consistent with our theoretical prediction that a higher creditor probability of winning results in more lawsuits. The erosion of sovereign immunity since the early 1980s was an important precondition for the strong increase in litigation which we observe in the data. Our other proxies of creditors' winning probability are economic openness and government legal capacity. As shown in column (2) both variables are significant and have the expected sign. The more open the country and the weaker its legal and administrative capacity, the more likely a restructuring will be accompanied by litigation.

Next, we show results for the role of restructuring characteristics, in particular the amount restructured and haircut size (column 3). Both are positively correlated with the probability of litigation. This is consistent with our own theoretical argument above, as well as with the models by Pitchford and Wright (2012a,b) and Bi et al. (2011). Surprisingly, however, we do not find a statistically significant coefficient for the bond restructuring dummy. Corporate borrowing costs, on the other hand, have a significant negative correlation with litigation (column 4), although this finding is not robust to all changes in model specifications that we attempt later on.

Column (5) shows our full model including all main explanatory variables and additional country-specific factors. As expected, we find countries with a higher share of debt issuances

\footnotetext{
${ }^{36}$ Specifically, we use the sample average share of sovereign bonds issued under US or UK law relative to the total amount of externally issued bonds. For countries with missing observations, we use data on governing laws of corporate bonds. Finally, for the subset of countries for which we do not have any data, we interpolate the variable from countries with the same legal origins according to Glaeser and Shleifer (2002).
} 
under US or UK governing law to be more likely to be sued in New York or London, but we do not find a significant effect of secondary market trading or GDP per capita. Arguably, the most notable insight from our full model is that the dummies on landmark judgments are now clearly insignificant, both individually and as a group, as confirmed by a standard Wald test for joint significance. Taken at face value, this result suggests that the legal environment is only a weak predictor of creditor litigation during debt crises. However, we are fully aware that our approach to capture legal doctrine is imperfect. What we can say with some confidence is that it does not suffice to account for legal factors only. Instead, we find that economic fundamentals and restructuring characteristics are surprisingly powerful predictors of litigation occurrence.

In terms of effect size, the variables on trade openness, haircuts, and restructuring volume seem to be particularly relevant. To see this, we refer to the marginal effect estimates in column (6), which shows how a one standard deviation increase in each of the variables (around their sample mean) changes the predicted probability of litigation, while holding all other variables constant at mean values. A one standard deviation increase in haircut size around the sample mean of $38 \%$ (from $24 \%$ to $52 \%$ ) is associated with an increase in the probability of litigation of 7 percentage points, i.e. from 7 to $14 \%$. Similarly, we find that an increase in deal size by one standard deviation increases the probability of litigation by 12 percentage points, while increasing the trade to GDP ratio from $45 \%$ to $83 \%$ raises the litigation probability by 5 percentage points.

The results are quantitatively and qualitatively similar when using our alternative dependent variables and estimation techniques. This is evident in columns (7) and (8), which use the number of lawsuits filed and the amount under litigation (in \% of total restructured debt), respectively. One notable change is that the coefficient for bond restructurings turns significant, suggesting that a more dispersed group of creditors increases case numbers and the amount under dispute. In addition, we now find the dummy for secondary market trading to be significant, although with a negative sign.

There are considerable time trends in our explanatory variables through the sample period. The predicted probability of litigation at the sample means for all variables is 9.7\%. However, this value disguises significant changes over time. For example, global average trade openness has increased from $38 \%$ during the average 1980 s to $52 \%$ since 
2000. Using the 1980s trade openness value and keeping all other variables constant at their sample mea), the predicted probability of litigation is $6.6 \%$. Using the average 2000s trade openness value, on the other hand, results in a predicted litigation risk of $8.2 \%$. This means that the change in global trade openness over the sample period corresponds to a two-percentage point increase in the estimated risk of litigation. Similar to the developments in trade openness, there has been an upward trend in haircuts. The average haircut size has increased from $26 \%$ in the 1980 s to $62 \%$ in recent years. Comparing the predicted probability at these two values implies a 10 percentage point increase in the predicted probability of litigation (from $7.0 \%$ to $16.7 \%$, again keeping the other variables at their sample mean). Finally, borrowing rates for high-yield debt have dropped from an average of about $15 \%$ during the 1980 s to less than $10 \%$ in the 2000 s. According to our baseline estimates, this drop in borrowing costs is associated with a 13 percentage point increase in the predicted risk of litigation (from $6 \%$ to 19\%). Considering these three variables together, the predicted probability of litigation at the average 1980s values amounted to only $3 \%$, compared to $27 \%$ at the average 2000 s values.

Importantly, however, we find that time trends do not appear to drive our main findings. Column (4) of Table 3 shows that the estimates are stable in a post-2000 sample, i.e. after the landmark Elliott judgment and during the 'modern' era of sovereign borrowing, featuring bond debt and increasing secondary market trading. The findings are also similar in the pre-2000 sample and when including decade fixed effects. We therefore conclude that the results discussed above are not spurious, and that our empirical model is robust to changes in market structure or global economic developments.

\subsection{Performance as "Early Warning System"}

How does the model perform as an early warning tool of creditor litigation? As a first assessment, we can apply the customary binary classification rule with a predicted probability threshold of 0.5. This shows that our benchmark model of column (5) in Table 2 correctly predicts litigation occurrence in $88 \%$ of restructuring events since the 1970 s. However, litigation is a rare event, with an unconditional probability of just $18 \%$ (base rate $=82 \%$ ), so that the $88 \%$ number masks the true model performance. Moreover, it is not clear a priori, whether the 0.5 threshold is appropriate for the data at hand: we face 
the classic trade-off between maximizing the sensitivity of the model (by trying to correctly predict each observed litigation case) or maximizing the model's specificity (by avoiding false positives, i.e. litigation predictions when it did in fact not occur).

A more objective evaluation tool is to estimate a receiver operating characteristic (ROC) curve, which does not require choosing an (arbitrary) classification probability cut-off, as illustrated for financial crisis prediction in Schularick and Taylor (2012). The ROC curve plots the true positive rate against the false positive rate for all possible probability cut-offs between 0 and 1 . The area under the curve (AUROC) can thus be interpreted as a generalized measure of model performance. An AUC value of 0.5 means that the model does not perform any better than tossing a coin for prediction (45-degree line), while a value of 1 indicates perfect classification. Thus, intuitively, the ROC curve illustrates how well the model predicts the outcome of interest compared to a random classification.

Figure 3 shows the ROC curve for our full benchmark model. The AUROC is 0.86 and it outperforms the benchmark coin-toss model at the $1 \%$ significance level. The AUROC is also notably higher than in any of the crisis prediction classifications in Schularick and Taylor (2012), who explain that values above 0.75 can be regarded as high, e.g. in medical trials. The second ROC curve shown is based on column (1) and includes only the legal era variables, i.e. the court decision time dummies, to account for the rising trend in litigation. The legal-only model also does well, with an AUROC statistic of 0.77, but our full model has a statistically significantly higher AUROC value. We thus conclude that our main specification with legal and economic variables performs reasonably well in explaining litigation events across the debt crises of the past decades.

\subsection{Robustness}

In Table 3 we conduct a series of robustness checks. For this purpose, we depart from our most conservative specification (column 5 of Table 2), which is the model that also shows the highest log likelihood. Overall, our main results remain stable.

Column (1) replaces trade openness with financial openness, which also turns out to be a statistically and economically significant predictor of litigation. Column (2) includes an indicator that captures whether the debt renegotiations were coordinated with a recognized creditor committee, as during most exchanges in the "London Club" era (data on creditor 
committees is taken from Trebesch (2010) and Das et al. (2012)). This dummy does not have a significant correlation with litigation risk and including it does not affect the results in any meaningful way.

The results also hold if we exclude the main outlier cases, in particular Argentina 2005 (column 4), or additionally Brazil 1994 and Peru 1997, which together account for more than two-thirds of the restructured debt in our sample period alone (column 5). Likewise, we find all main results to be stable when controlling for regional effects, i.e. dummies for Latin American and African countries, which are the two continents with most sovereign debt litigation cases (column 6). In column (7) we exclude cases of strictly pre-emptive restructurings based on a new dataset by Asonuma and Trebesch (2014). Strictly preemptive deals are those in which no payments are missed during the restructuring process. The results remain stable when dropping these non-default cases. The same is true when we consider the forum where litigation takes place. Of the 121 lawsuits in our sample, 104 were filed in the US, 14 in the UK, and 3 were brought to international arbitration tribunals. Column (8) presents results when restricting the sample only to lawsuits filed in US courts. While the marginal effect on the government effectiveness variable is no longer significant, the effect direction does not change and its size remains at a considerable level.

In a next step, we interact the main variables of interest with our measure of deal size (column 3). The idea is to check whether there is an interaction between the volume of the debt restructuring and the correlation of the main variables with the probability of litigation. Such an interaction could arise, for instance, if the government suffers a fixed cost from litigating creditors. In that case, the value of settling with litigating holdout creditors would be larger for larger debt volumes. A holdout creditor disrupting a large debt restructuring would then have greater leverage, making these deals more attractive targets for distressed debt investors. Empirically, we estimate a variation of our benchmark model as:

$$
\begin{aligned}
& \operatorname{Prob}(Y=1 \mid \mathbf{X}, Z, \text { Debt Amount })= \\
& \Phi\left(\beta_{1} Z+\beta_{2} \text { Debt Amount }+\beta_{3} Z \times \text { Debt Amount }+\mathbf{X}^{\prime} \boldsymbol{\beta}\right)
\end{aligned}
$$

Table 4 shows the results. All main results remain consistent with the previous findings 
after controlling for interactions with the deal size. Haircut size appears irrelevant for small debt restructurings (less than USD $200 \mathrm{~m}$ ), but its marginal effect increases strongly with the volume of debt involved. For example, for very large debt exchanges (more than USD $3 \mathrm{bn}$ ), a one standard deviation increase in haircuts can be associated with a more than 16 percentage points higher risk of litigation (from 13 to 29\%). This result suggests that a high haircut is much more likely to end up in court if the number of affected creditors is also high. Since the coefficient on the interaction term in non-linear models cannot be sensibly interpreted, ${ }^{37}$ we also show the marginal effects obtained from the interaction models as a function of the debt volume in figure 4 . The marginal effects for all main variables except the bond restructuring indicator keep their sign for all observed deal volumes. However, the statistical significance varies slightly. Whereas the trade/GDP ratio and the government effectiveness have a significant effect for medium-sized restructurings, the haircut and the corporate yield are significant for the restructurings above the median debt volume in our sample. As in the main results, the marginal effect on the bond restructuring variable is insignificant throughout.

Finally, we account for endogeneity of the haircut. In line with our theoretical framework, haircuts could be partly endogenous, because governments anticipate creditors to file suit when facing high losses. This would result in a downward bias in the estimated haircut coefficient, since our main result is based on a sample of debt restructurings with high haircuts that were imposed despite the threat of creditor litigation. Table 5 shows results when running instrumental variable regressions using the lagged debt/GDP ratio as an instrument for haircut size, for both probit and linear probability models in the second stage. The results indicate that our baseline haircut coefficients are indeed downward biased. The average marginal effect of haircut size is about twice as large compared to our benchmark model. The instrument performs well with respect to standard specification statistics. We are able to reject the null of a weak instrument, which further increases our

\footnotetext{
${ }^{37}$ In non-linear models with interactions between independent variables, the marginal effect of the interacted variables depend non-linearly on the level of the other variable. This implies that the coefficient on the interaction term cannot be meaningfully interpreted, see the discussion by Greene (2010). In equation (9), the marginal effect for a change in $Z$ is given by

$$
\frac{\partial \operatorname{Pr}(Y=1)}{\partial Z}=\phi\left(\beta_{1} Z+\beta_{2} \text { Debt Amount }+\beta_{3} Z \times \text { Debt Amount }+\mathbf{X}^{\prime} \boldsymbol{\beta}\right)\left(\beta_{1}+\beta_{3} \text { Debt Amount }\right)
$$
instead of the raw coefficients, and supplement the results with the graphs in figure 4 .
} 
confidence in the regression results. ${ }^{38}$

\section{Conclusion}

This paper studies a prominent type of creditor coordination problems in the context of sovereign debt defaults: holdout litigation. We find that litigation against defaulting sovereigns can be explained reasonably well within a simple framework from the law and economics literature. Similar to other fields of law, sovereign debt lawsuits are more likely

(i) when the damage is large, i.e. in case of high haircuts and larger restructuring amounts, (ii) when litigation costs are low for the plaintiffs, i.e. when borrowing costs are low, and (iii) when the defendant is vulnerable, e.g. when the defaulting country has a high degree of financial and trade openness. These insights may be relevant for the ongoing reform debate on sovereign debt and default, for theory work in international finance, and for scholars working on litigation in other fields.

Looking forward, our findings suggest that creditor litigation will remain relevant and potentially increase further. Most debtor countries are open economies, which facilitates attachments and increases the chance of creditors to achieve a favorable settlement. Borrowing costs continue to be low, which means that holding out is relatively cheap. Moreover, we are witnessing an increase in government indebtedness worldwide, which makes it likely that future debt restructurings may involve large debt amounts and also result in high haircuts, thus raising the probability of creditor litigation. Besides these economic trends, recent litigation successes against Argentina and Ireland have arguably strengthened creditor rights further, and may thus encourage more distressed debt funds to hold out and litigate in future debt exchanges (see Buchheit et al., 2013b). At the same time, the issuance of debt under New York and English law could become an increasingly relevant commitment device for sovereigns, since defaults on these types of bonds can have costly legal consequences. This has already happened in Greece, which issued its new bonds under English law to signal its willingness to pay (Gulati and Zettelmeyer, 2012).

\footnotetext{
${ }^{38}$ We also considered using IMF programs at the time of restructuring as an instrument, to capture the effect of IMF pressure on haircut size. The instrument performed very weakly, which is why we do not show the results. However, including both the debt/GDP ratio and the IMF indicator as instruments allows testing the exclusion restriction. Based on the resulting Hansen's J statistic, we could not reject the null of valid instruments, which supports our choice of the debt/GDP ratio as an instrument for haircuts.
} 


\section{References}

Abbas, Ali, Nazim Belhocine, Asmaa El Ganainy, and Mark Horton. 2010. A Historical Public Debt Database, IMF Working Paper No. 10/245.

Aguiar, Mark and Manuel Amador. 2013. Sovereign debt, Handbook of International Economics, 4.

Alfaro, Laura, Noel Maurer, and Ahmed Faisal. 2010. Gunboats and Vultures: Market Reaction to the "Enforcement" of Sovereign Debt, mimeo, UCLA.

Asonuma, Tamon and Christoph Trebesch. 2014. Sovereign Debt Restructurings: Preemptive or Post-Default, mimeo, University of Munich.

Beshkar, Mostafa. 2013. Arbitration and Renegotiation in Trade Agreements, mimeo, University of New Hampshire.

Bi, Ran, Marcos Chamon, and Jeromin Zettelmeyer. 2011. The Problem that Wasn't: Coordination Failures in Sovereign Debt Restructurings, IMF Working Paper No. 11/265.

Blackman, Jonathan I. and Rahul Mukhi. 2010. The evolution of modern sovereign debt litigation: Vultures, alter egos, and other legal fauna, Law and Contemporary Problems, $73(4), 47-62$.

Bolton, Patrick. 2003. Toward a Statutory Approach to Sovereign Debt Restructuring: Lessons from Corporate Bankruptcy Practice around the World, IMF Working Paper No. $03 / 13$.

Bolton, Patrick and Olivier Jeanne. 2007. Structuring and restructuring sovereign debt: The role of a bankruptcy regime, Journal of Political Economy, 115(6), 901-924.

Bolton, Patrick and Olivier Jeanne. 2009. Structuring and restructuring sovereign debt: The role of seniority, The Review of Economic Studies, 76(3), 879-902.

Bown, Chad. 2004. On the economic success of GATT/WTO dispute settlement, Review of Economics and Statistics, 86(3), 811-823.

Bown, Chad. 2005a. Participation in WTO dispute settlement: Complainants, interested parties and free riders, World Bank Economic Review, 19(2), 287-310.

Bown, Chad. 2005b. Trade remedies and World Trade Organization dispute settlement: Why are so few challenged?, Journal of Legal Studies, 34(2), 515-555.

Bradley, Michael, James Cox, and G. Mitu Gulati. 2010. The market reaction to legal shocks and their antidotes: Lessons from the sovereign debt market, Journal of Legal Studies, 39(1), 289-324.

Broomfield, Elizabeth. 2010. Subduing the vultures: Assessing government caps on recovery in sovereign debt litigation, Columbia Business Law Review, 473-528.

Brown Rudnick. 2012. Vulture funds take note, Strong Suit Alert, URL http://www.brownrudnick.com/uploads/114/doc/Brown_Rudnick_Vulture_Funds_ Take_Note.pdf.

Buchheit, Lee C. 1999. Sovereign debt litigation, Memorandum for the International Monetary Fund, February 04, 1999. 
Buchheit, Lee C., Anna Gelpern, G. Mitu Gulati, Ugo Panizza, Beatrice Weder Di Mauro, and Jeromin Zettelmeyer. 2013a. Revisiting Sovereign Bankruptcy, Washington D.C.: Brookings Institution.

Buchheit, Lee C., G. Mitu Gulati, and Ignacio Tirado. 2013b. The Problem of Holdout Creditors in Eurozone Sovereign Debt Restructurings, mimeo, Duke University.

Bulow, Jeremy and Kenneth Rogoff. 1989a. A constant recontracting model of sovereign debt, Journal of Political Economy, 97(1), 155-178.

Busch, Marc and Eric Reinhardt. 2003. Developing countries and General Agreement on Tariffs and Trade/World Trade Organization dispute settlement, Journal of World Trade, 37(4), 719-735.

Busch, Marc L. and Eric Reinhardt. 2006. Three's a crowd: Third parties and WTO dispute settlement, World Politics, 58(3), 446-477.

Calvo, Guillermo. 1988. Servicing the public debt: The role of expectations, American Economic Review, 78(4), 647-661.

Cameron, A. and P. Trivedi. 1986. Econometric models based on count data: Comparisons and applications of some estimators and tests, Journal of Applied Econometrics, 46, $347-364$.

Cleary Gottlieb Steen \& Hamilton and Clifford Chance. 1992. Avoiding the nightmare scenario, International Financial Law Review, 11, 19-22.

Coase, Ronald. 1960. The problem of social cost, Journal of Law and Economics, 3(1), $1-44$.

Cooter, Robert D. and Daniel L. Rubinfeld. 1989. Economic analysis of legal disputes and their resolution, Journal of Economic Literature, 27, 1067-1097.

Cruces, Juan J. and Christoph Trebesch. 2013. Sovereign defaults: The price of haircuts, American Economic Journal: Macroeconomics, 5(3), 1-34.

Das, Udaibir, Michael Papaioannou, and Christoph Trebesch. 2012. Sovereign Debt Restructurings 1950-2010: Literature Survey, Data, and Stylized Facts, IMF Working Paper No. $12 / 203$.

Davis, Christina and Sarah Bermeo. 2009. Who files? Developing country participation in GATT/WTO adjudication, Journal of Politics, 71(3), 1033-1049.

Dooley, Michael P. 2000. International financial architecture and strategic default: Can financial crises be less painful?, Carnegie-Rochester Conference Series on Public Policy, 53(1), 361-377.

EMTA. 2009. Creditor Litigation in the Non-HIPC Sovereign Debt Restructuring Context, Paper prepared for Club de Paris Meeting.

Enderlein, Henrik, Christoph Trebesch, and Laura von Daniels. 2012. Sovereign debt disputes, Journal of International Money and Finance, 31(2), 250-266.

Engelen, Christian and Johann Lambsdorff. 2009. Hares and stags in Argentinean debt restructuring, Journal of International Economics, 78(1), 141-148. 
Erce, Aitor. 2013. Sovereign Debt Restructurings and the IMF: Implications for Future Official Interventions, Federal Reserve Bank of Dallas Working Paper No. 143.

European Commission. 2012. EU accountability report 2012 on financing for development, Staff Working Paper, URL http://ec.europa.eu/ europeaid/what/development-policies/financing_for_development/documents/ swp-199-main-report.pdf.

Fisch, Jill E. and Caroline M. Gentile. 2004. Vultures or vanguards? The role of litigation in sovereign debt restructuring, Emory Law Journal, 53, 1043-1114.

Foster, George K. 2008. Collecting from sovereigns: The current legal framework for enforcing arbitral awards and court judgments against states and their instrumentalities, and some proposals for its reform, Arizona Journal of International $\& 3$ Comparative Law, $25(3), 666-731$.

Gai, Prasanna, Somon Hayes, and Hyun Song Shin. 2004. Crisis costs and debtor discipline: The efficacy of public policy in sovereign debt crises, Journal of International Economics, $62(2), 245-262$.

Gelpern, Anna. 2005. After Argentina, Institute for International Economics Policy Brief No. $05 / 02$.

Ghosal, Sayantan and Marcus Miller. 2003. Co-ordination failure, moral hazard and sovereign bankruptcy procedures, Economic Journal, 113(487), 276-304.

Ghosal, Sayantan and Kannika Thampanishvong. 2013. Does strengthening Collective Action Clauses (CACs) help?, Journal of International Economics, 89(1), 68-78.

Gianviti, Francois, Anne Krueger, Jean Pisany-Ferry, André Sapir, and Jürgen von Hagen. 2010. A European Mechanism for Sovereign Debt Crisis Resolution: A Proposal, Brussels: Bruegel.

Glaeser, E. L. and A. Shleifer. 2002. Legal origins, The Quarterly Journal of Economics, $117(4), 1193-1229$.

Goldman, Samuel E. 2000. Mavericks in the market. The emerging problem of hold-outs in sovereign debt restructuring, UCLA Journal of International and Foreign Affairs, 5(1), 159-198.

Greene, William H. 2010. Testing hypotheses about interaction terms in nonlinear models, Economics Letters, 107(2), 291-296.

Grinols, Earl L. and Roberto Perrelli. 2006. The WTO impact on international trade disputes: An event history analysis, Review of Economics and Statistics, 88(4), 613-624.

Gulati, Mitu and Robert E. Scott. 2012. The Three and a Half Minute Transaction: Boilerplate and the Limits of Contract Design, Chicago: University of Chicago Press.

Gulati, Mitu and Jeromin Zettelmeyer. 2012. Making a voluntary Greek debt exchange work, Capital Markets Law Journal, 7, 169-183.

Haldane, Andrew, Adrian Penalver, Victoria Saporta, and Hyung Shin. 2005. The analytics of sovereign debt restructuring, Journal of International Economics, 65(2), 315-333. 
Hurlock, James B. 1984a. Advising sovereign clients on the renegotiation of their external indebtedness, Columbia Journal of Transnational Law, 23, 29-48.

Hurlock, James B. 1984b. The legal treatment of sovereign default: The borrower's perspective, in David Suratgar, (Ed.) Default and Rescheduling: Corporate and Sovereign Borrowers in Difficulty, Washington D.C.: Euromoney Publications, Chapter 12.

IIF. 2009. Creditor Litigation in Low-Income Countries Benefiting from the Enhanced-HIPC and MDRI, Paper prepared for Club de Paris Meeting.

IMF. 2002. Global Financial Stability Report, Washington D.C.: IMF.

IMF. 2003. Proposed Features of a Sovereign Debt Restructuring Mechanism, Washington D.C.: IMF.

IMF. 2013. Sovereign Debt Restructuring. Recent Developments and Implications for the Fund's Legal and Policy Framework, Washington D.C.: IMF.

Kaufmann, Daniel, Aart Kraay, and Massimo Mastruzzi. 2010. The Worldwide Governance Indicators: A Summary of Methodology, Data and Analytical Issues, World Bank Policy Research Working Paper No. 5430, URL http://info.worldbank.org/governance/ wgi/index.asp.

Krueger, Anne. 2002. A New Approach to Sovereign Debt Restructuring, Washington D.C.: IMF, URL http://www.imf .org/external/pubs/ft/exrp/sdrm/eng/index.htm.

Lanau, Sergi. 2011. The Contractual Approach to Sovereign Debt Restructuring, Bank of England Working Paper No. 409.

Landes, William. 1971. An economic analysis of the courts, Journal of Law and Economics, 14(1), 61-107.

Lane, Philip R. and Gian Maria Milesi-Ferretti. 2007. The external wealth of nations mark II: Revised and extended estimates of foreign assets and liabilities, 1970-2004, Journal of International Economics, 73(2), 223-250.

Lanjouw, Jean and Josh Lerner. 1997. The Enforcement of Intellectual Property Rights: A Survey of the Empirical Literature, NBER Working Paper Series No. 6296.

Lerner, Josh. 2010. The litigation of financial innovations, Journal of Law and Economics, $53(4), 807-831$.

Maggi, Giovanni and Robert W. Staiger. 2011. The role of dispute settlement procedures in international trade agreements, The Quarterly Journal of Economics, 126(1), 475-515.

Maggi, Giovanni and Robert W. Staiger. 2013. Trade Disputes and Settlement, mimeo, Yale University.

Marchesi, Silvia. 2003. Adoption of an IMF programme and debt rescheduling. an empirical analysis, Journal of Development Economics, 70(2), 403-423.

Mendoza, Enrique G. and Vivian Z. Yue. 2012. A general equilibrium model of sovereign default and business cycles, Quarterly Journal of Economics, 127(2), 889-946.

Miller, Marcus and Dania Thomas. 2007. Sovereign debt restructuring: The judge, the vultures and creditor rights, The World Economy, 30(10), 1491-1509. 
Miller, Marcus and Lei Zhang. 2000. Sovereign liquidity crises: The strategic case for a payments standstill, Economic Journal, 110(460), 335-362.

Mody, Ashoka. 2013. Sovereign Debt and its Restructuring Framework in the Euro Area, Bruegel Working Paper 2013/05.

Pitchford, Rohan and Mark L. J. Wright. 2007. Restructuring the Sovereign Debt Restructuring Mechanism, mimeo, UCLA, URL http://www.econ.ucla.edu/mlwright/ research/workingpapers/RSDRM.pdf.

Pitchford, Rohan and Mark L. J. Wright. 2010. Holdouts in Sovereign Debt Restructuring: A Theory of Negotiation in a Weak Contractual Environment, NBER Working Paper No. 16632.

Pitchford, Rohan and Mark L. J. Wright. 2012a. Holdouts in sovereign debt restructurings: A theory of negotiations in a weak contractual environment, Review of Economic Studies, $79(2), 1-26$.

Pitchford, Rohan and Mark L. J. Wright. 2012b. Strategic Behavior in Sovereign Debt Restructuring: Impact and Policy Responses, mimeo, UCLA.

Posner, Richard. 1973. An economic approach to legal procedure and judicial administration, Journal of Legal Studies, 2(2), 399-458.

Priest, George and Benjamin Klein. 1984. The selection of disputes for litigation, Journal of Legal Studies, 13(1), 1-56.

Rogoff, Kenneth and Jeromin Zettelmeyer. 2002. Bankruptcy procedures for sovereigns: A history of ideas, 1976-2001, IMF Staff Papers, 49(3), 470-507.

Rose, A. K. 2005. One reason countries pay their debts: Renegotiation and international trade, Journal of Development Economics, 77(1), 189-206.

Roubini, Nouriel. 2010. An orderly market-based approach to the restructuring of Eurozone sovereign debts obviates the need for statutory approaches, RGE Analysis, 15 Nov. 2010, URL http://www.roubini.com/analysis/138863.php.

Roubini, Nouriel and Brad Setser. 2004. Bailouts or Bail-ins? Responding to Financial Crises in Emerging Economies, Washington D.C.: Institute for International Economics.

Sandleris, Guido. 2012. The Costs of Sovereign Defaults: Theory and Empirical Evidence, Universidad Torcuato Di Tella Working Paper No. 02/2012.

Sawada, Yasuyuki. 2001. Secondary market efficiency for LDC bank loans and international private lending, 1985-1993, Journal of International Money and Finance, 20(4), 549-562.

Schularick, Moritz and Alan M. Taylor. 2012. Credit booms gone bust: Monetary policy, leverage cycles, and financial crises, 1870-2008, American Economic Review, 102(2), 1029-1061.

Schumacher, Julian, Christoph Trebesch, and Henrik Enderlein. 2014. Sovereign Defaults in Court, mimeo, University of Munich.

Scott, Hal S. 2006. Sovereign Debt Default: Cry for the United States, Not Argentina, Washington Legal Foundation Working Paper Series No. 140. 
Shleifer, Andrei. 2003. Will the sovereign debt market survive?, American Economic Review - Papers and Proceedings, 93(2), 85-90.

Singh, Manmohan. 2003. Recovery Rates from Distressed Debt - Empirical Evidence from Chapter 11 Filings, International Litigation, and Recent Sovereign Debt Restructurings, IMF Working Paper No. 03/161.

Spier, Kathryn. 2007. Litigation, in Mitchell Polinsky and Steven Shavell, (Eds.) Handbook of Law and Economics, Amsterdam: Elsevier, vol. 1, 265-345.

Sturzenegger, Federico and Jeromin Zettelmeyer. 2006. Debt Defaults and Lessons from a Decade of Crises, Cambridge: MIT Press.

Sturzenegger, Federico and Jeromin Zettelmeyer. 2008. Haircuts: Estimating investor losses in sovereign debt restructurings, 1998-2005, Journal of International Money and Finance, $27,780-805$.

Tirole, Jean. 2012. The Euro crisis: Some reflexions on institutional reform, Financial Stability Review, 16, 225-242.

Trebesch, Christoph. 2010. Delays in Sovereign Debt Restructurings, mimeo, Free University Berlin.

Waibel, Michael. 2011. Sovereign Defaults before International Courts and Tribunals, Cambridge: Cambridge Univ. Press.

Weder Di Mauro, Beatrice and Jeromin Zettelmeyer. 2010. European debt restructuring mechanism as a tool for crisis prevention, VoxEU, November 26, 2010, URL http://www.voxeu.org/article/ european-debt-restructuring-mechanism-tool-crisis-prevention.

Weidemaier, Mark C. 2014. Sovereign immunity and sovereign debt, University of Illinois Law Review, forthcoming.

Weinschelbaum, Federico and Josef Wynne. 2005. Renegotiation, collective action clauses and sovereign debt markets, Journal of International Economics, 67(1), 47-72.

Wheeler, Christopher and Amir Attaran. 2003. Declawing the vulture funds: Rehabilitation of a comity defense in sovereign debt litigation, Stanford Journal of International Law, $39,253-284$. 


\section{Figures}

Figure 1: The rise of creditor litigation (Case Numbers and Volumes)

The bars show the number of outstanding creditor lawsuits against sovereigns in US and UK courts for each year between 1978 and 2010 (pending cases, left axis). The orange line represents the share of debt restructurings per year which saw at least one creditor filing a lawsuit (5-year moving average, right axis). The figure shows a strong increase in case numbers and litigation risk over the past decades.

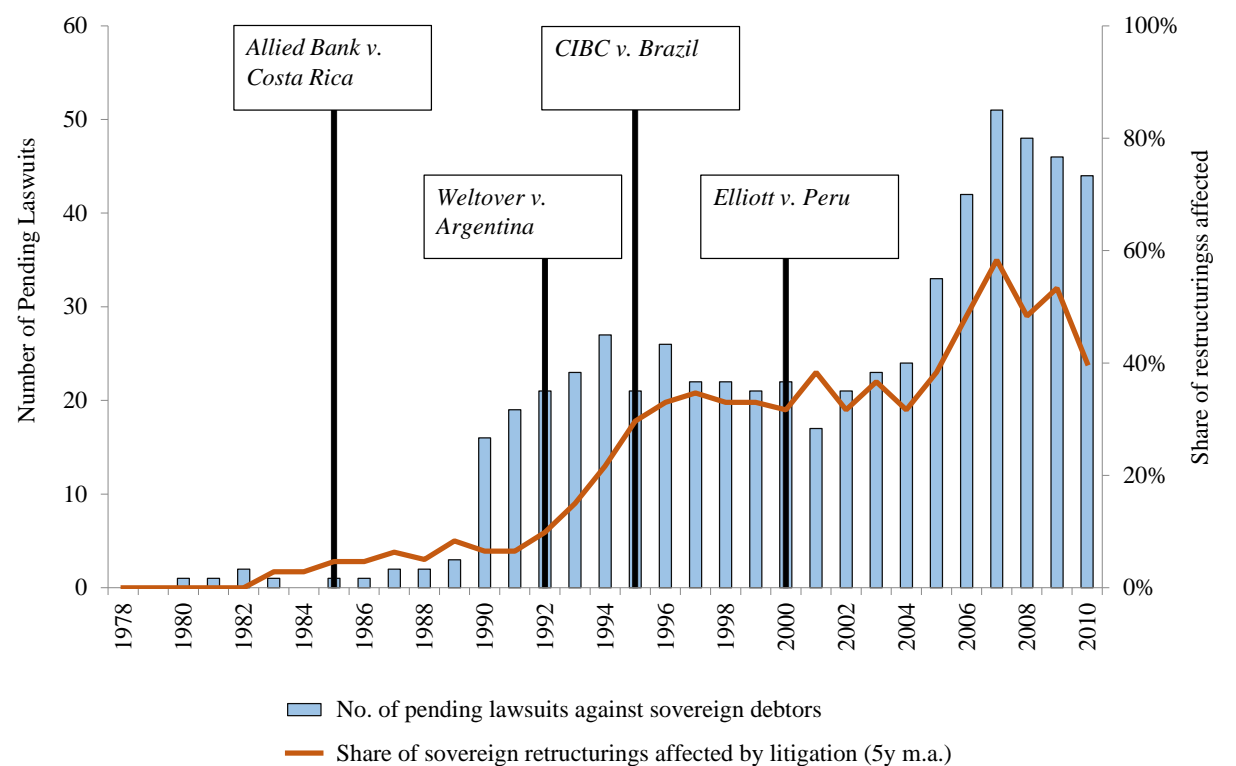


Figure 2: The role of deal sizes and haircuts

The figure shows restructurings with and without litigation in the full sample 1978-2010, where red colored deals are those involving at least one creditor lawsuit. The circle size reflects the volume of restructured debt in real USD (indexed to 2005), while the vertical axis shows the size of haircuts, based on the preferred estimates by Cruces and Trebesch (2013). The figure suggests that recent restructurings were more often affected by litigation, especially those with high haircuts and large debt amounts (high creditor numbers).

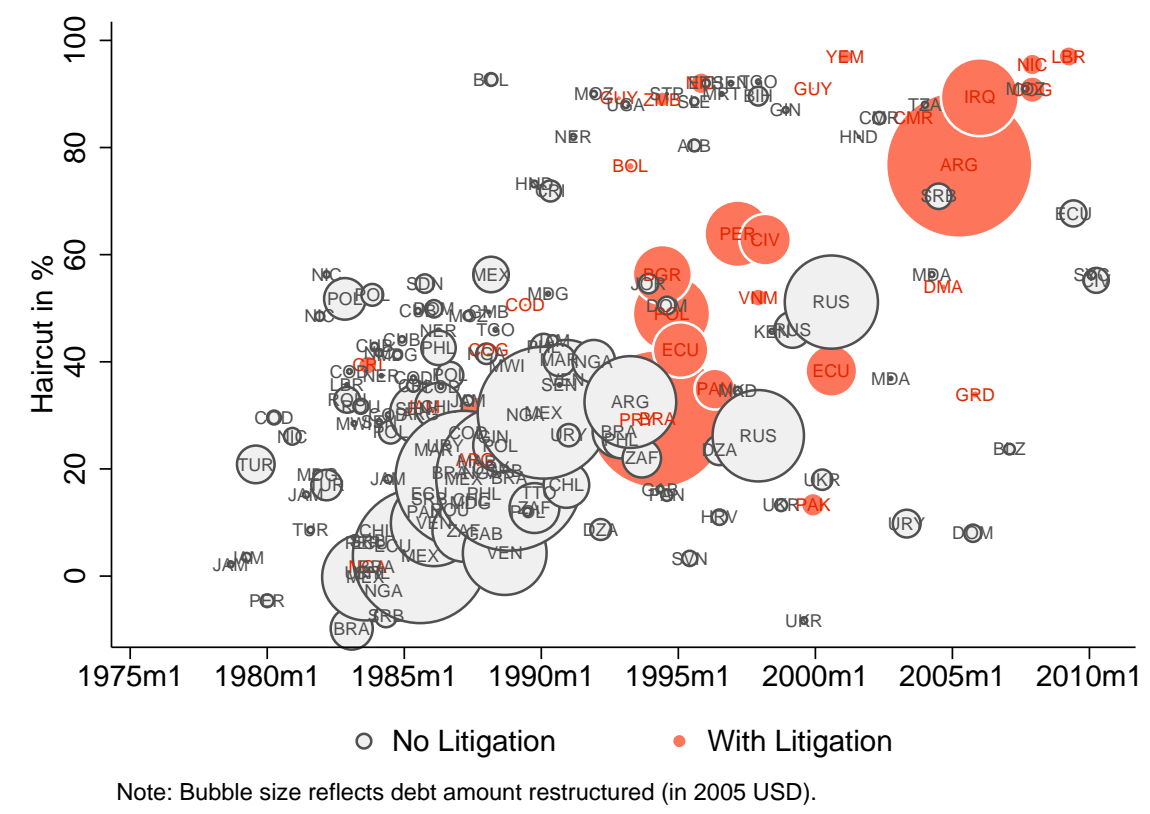


Figure 3: ROC curves of model performance

This figure shows estimated ROC curves based on the models of column (1) (legal only) and (6) (full model) from Table 2. The horizontal axis shows the false positive rate, i.e. the probability of diagnosing litigation if there is none, against the true positive rate (vertical axis) for all possible probability cut-off levels. Intuitively, the curve illustrates how well the model performs as a predictor tool compared to a random classification model ("coin toss", represented by the 45-degree line). A curve closer to the upper left corner indicates better model fit, which will also be captured by the area under the ROC curve (AUROC) statistic. This ranges from 0.5 for a coin toss model to a value of 1 for a model with perfect classification.

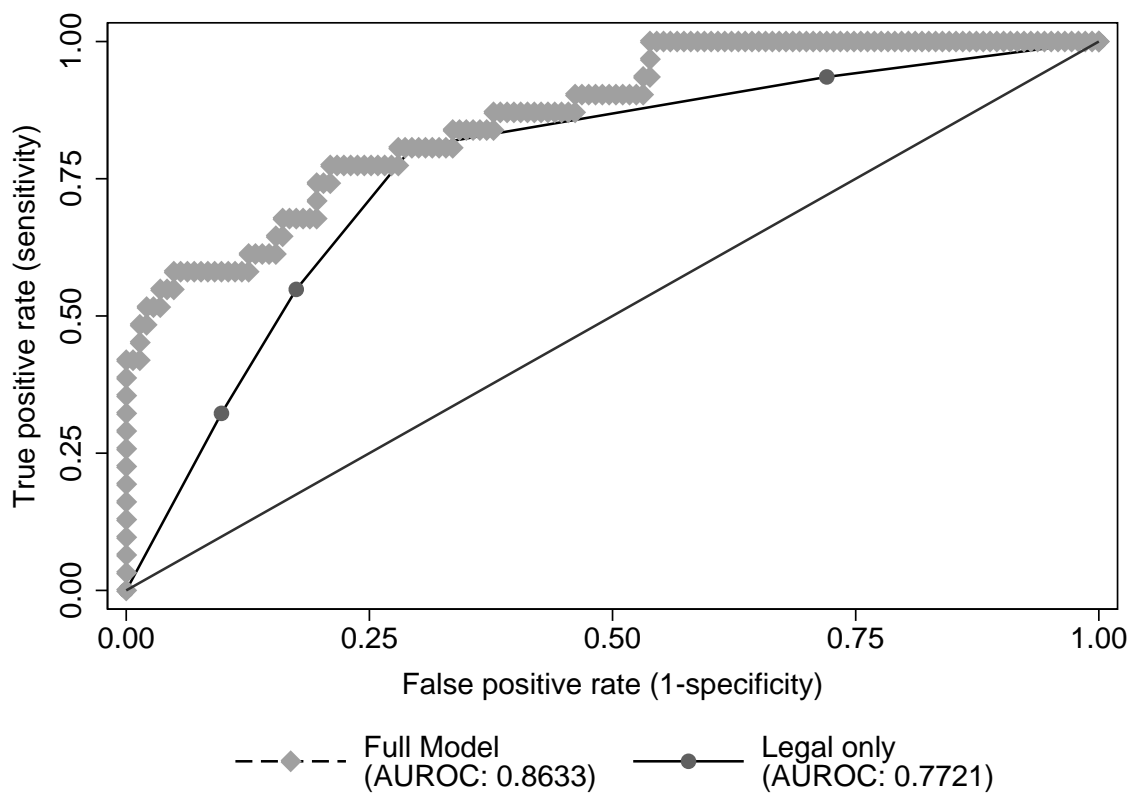


Figure 4: Interactions of main variables with debt volume

This figure shows the average marginal effects of the main variables from table 4 as a function of the restructured debt volume (in logs). The dark grey line represents the marginal effect, and the light grey lines mark the $95 \%$ confidence interval around the estimate. The red vertical lines mark the median deal size (USD 1bn). Note that the marginal effect is a non-linear function of the other variables in the model (see footnote 37 ).
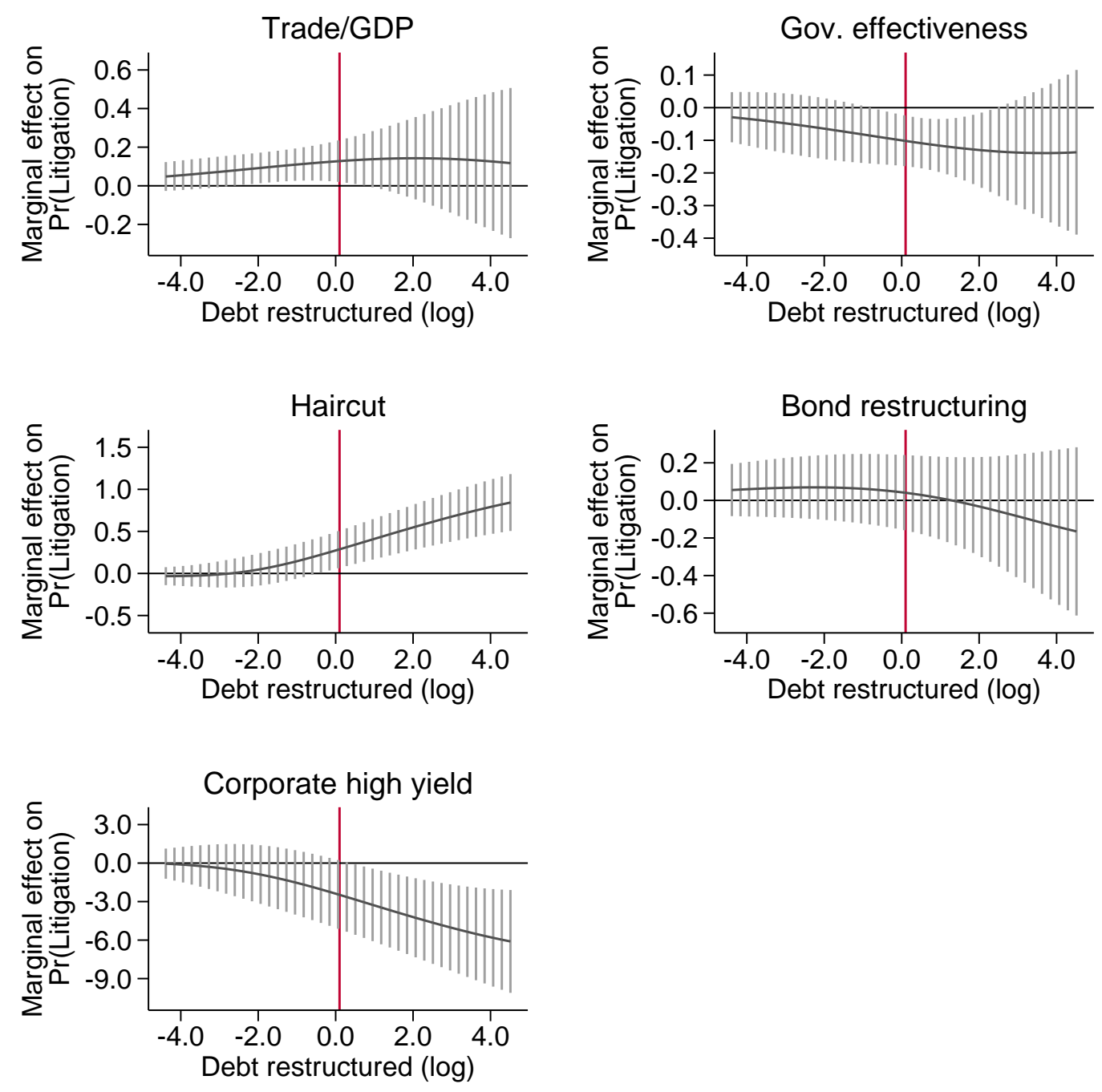


\section{Tables}

Table 1: Variable definition, sources, and summary statistics

\begin{tabular}{|c|c|c|c|c|c|c|c|}
\hline Variable & Definition & Source & Mean & Std. Dev. & Min. & Max. & $\mathrm{N}$ \\
\hline Litigation & Dummy ( 1 if at least one investor filed suit) & This dataset & 0.18 & 0.38 & 0 & 1 & 174 \\
\hline Litigation (sum of cases) & Number of filed cases in connection with restructuring & This dataset & 0.70 & 3.47 & 0 & 41 & 174 \\
\hline $\begin{array}{l}\text { Litigation (share of restruc- } \\
\text { tured debt) }\end{array}$ & $\begin{array}{l}\text { Ratio of principal in litigation to total restructured } \\
\text { debt }\end{array}$ & This dataset & 0.01 & 0.03 & 0 & 0.22 & 172 \\
\hline Openness to trade & Exports plus imports as a percentage of GDP & $\begin{array}{l}\text { World Bank WDI, IMF Direction of } \\
\text { Trade Statistics }\end{array}$ & 0.64 & 0.38 & 0.09 & 2.8 & 174 \\
\hline Government effectiveness & $\begin{array}{l}\text { "Government Effectiveness" index measuring multiple } \\
\text { dimensions of bureaucratic and legal capacity }\end{array}$ & $\begin{array}{l}\text { World Bank Governance Indicators, } \\
\text { Kaufmann et al. (2010) }\end{array}$ & -0.36 & 0.64 & -1.78 & 1.2 & 174 \\
\hline Haircut (PV) & $\begin{array}{l}\text { Creditor losses in the restructuring in percent, com- } \\
\text { puted in present value terms (following Sturzenegger } \\
\text { and Zettelmeyer (2008)) }\end{array}$ & Cruces and Trebesch (2013) & 0.38 & 0.28 & -0.10 & 0.97 & 174 \\
\hline Debt restructured (log) & Log of amount of dollars restructured (in 2005 USD) & Cruces and Trebesch (2013) & 0.08 & 2.04 & -4.39 & 4.52 & 174 \\
\hline Bond restructuring & Dummy ( 1 for restructurings of sovereign bonds) & Cruces and Trebesch (2013) & 0.10 & 0.30 & 0 & 1 & 174 \\
\hline Corporate high yield & Average yield of Baa rated corporate bonds in the US & Barclays / Lehman Brothers & 0.13 & 0.03 & 0.07 & 0.18 & 174 \\
\hline GDP per capita $(\log )$ & Log of 1980 GDP per capita & United Nations National Accounts & 7.54 & 1.20 & 4.22 & 10.58 & 174 \\
\hline Secondary market & $\begin{array}{l}\text { Dummy ( } 1 \text { if a liquid secondary market for debt ex- } \\
\text { isted) }\end{array}$ & $\begin{array}{l}\text { JP Morgan EMBI; Sawada (2001) (for } \\
\text { 1980s) }\end{array}$ & 0.28 & 0.45 & 0 & 1 & 174 \\
\hline $\begin{array}{l}\text { US, UK/Total external } \\
\text { debt }\end{array}$ & $\begin{array}{l}\text { External debt issued under US or UK law as percent- } \\
\text { age of total external debt }\end{array}$ & Dealogic Bondware & 0.45 & 0.31 & 0 & 1 & 174 \\
\hline Financial openness & Assets plus liabilities as a percentage of GDP & Lane and Milesi-Ferretti (2007) & 1.45 & 1.24 & 0.18 & 9.96 & 162 \\
\hline Creditor Committee & $\begin{array}{l}\text { Dummy ( } 1 \text { if the debt renegotiations were conducted } \\
\text { by a recognized creditor committe of banks and/or } \\
\text { bondholders) }\end{array}$ & Trebesch (2010); Das et al. (2012) & 0.93 & 0.25 & 0 & 1 & 173 \\
\hline Debt/GDP (Log, Lag) & Gross general government debt scaled to nominal GDP & Abbas et al. (2010) & -0.3 & 0.61 & -1.77 & 2.06 & 154 \\
\hline
\end{tabular}


Table 2: Main results: Creditor litigation in sovereign debt restructurings 1978-2010

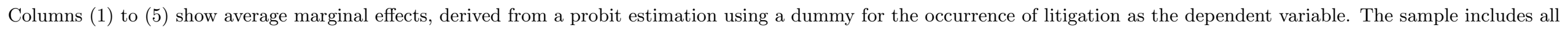

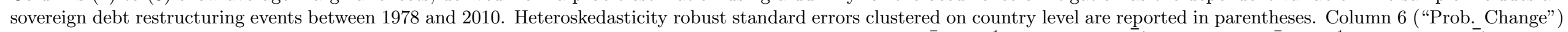

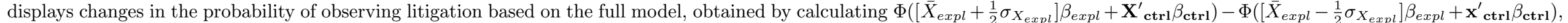

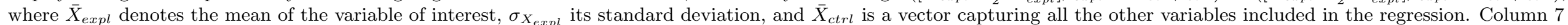

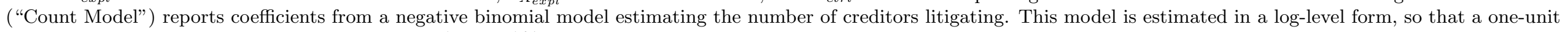

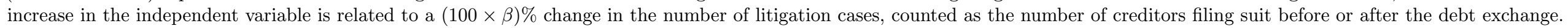

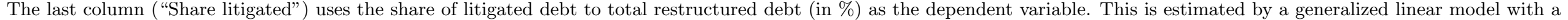
probit link function.

\begin{tabular}{|c|c|c|c|c|c|c|c|c|}
\hline & (1) & (2) & (3) & $(4)$ & (5) & (6) & (7) & $(8)$ \\
\hline & $\begin{array}{l}\text { Legal Con- } \\
\text { trols only }\end{array}$ & $\begin{array}{l}\text { Probability of } \\
\text { Success }\end{array}$ & $\begin{array}{lr}\text { With } & \text { Re- } \\
\text { struct. } & \text { Char- } \\
\text { act. } & \\
\end{array}$ & Creditor Cost & $\begin{array}{l}\text { Full Model w/ } \\
\text { Controls }\end{array}$ & $\begin{array}{l}\text { Prob. } \\
\text { Change }\end{array}$ & Count Model & $\begin{array}{l}\text { Share Liti- } \\
\text { gated }\end{array}$ \\
\hline Post Allied ('85-'91) & $\begin{array}{l}0.027 \\
(0.095)\end{array}$ & & & & $\begin{array}{l}-0.042 \\
0.094)\end{array}$ & -0.040 & $\begin{array}{l}-1.627 \\
(1.066)\end{array}$ & $\begin{array}{l}-0.005 \\
(0.007)\end{array}$ \\
\hline Post Weltover ('92-'94) & $\begin{array}{l}0.297 * * * \\
(0.092)\end{array}$ & & & & $\begin{array}{l}0.072 \\
0.134)\end{array}$ & 0.022 & $\begin{array}{l}-1.381 \\
(1.088)\end{array}$ & $\begin{array}{l}-0.012 \\
(0.010)\end{array}$ \\
\hline Post CIBC ('95-'99) & $\begin{array}{l}0.257^{* * *} \\
(0.095)\end{array}$ & & & & $\begin{array}{l}-0.003 \\
0.136)\end{array}$ & -0.003 & $\begin{array}{l}-1.353 \\
(1.044)\end{array}$ & $\begin{array}{l}-0.010 \\
(0.010)\end{array}$ \\
\hline Post Elliott ('00-'10) & $\begin{array}{l}0.312^{* * *} \\
(0.093)\end{array}$ & & & & $\begin{array}{l}0.000 \\
0.142)\end{array}$ & 0.000 & $\begin{array}{l}-1.629 \\
(1.087)\end{array}$ & $\begin{array}{l}-0.017^{* *} \\
(0.008)\end{array}$ \\
\hline Openness to trade & & $\begin{array}{l}0.163^{* *} \\
(0.066)\end{array}$ & & & $\begin{array}{l}0.136^{* *} \\
0.057)\end{array}$ & 0.051 & $\begin{array}{l}0.864^{* * *} \\
(0.294)\end{array}$ & $\begin{array}{l}0.010^{* * *} \\
(0.003)\end{array}$ \\
\hline Gov. effectiveness & & $\begin{array}{l}-0.085^{* *} \\
(0.041)\end{array}$ & & & $\begin{array}{l}-0.101^{* * *} \\
0.039)\end{array}$ & -0.063 & $\begin{array}{l}-0.949^{* * *} \\
(0.334)\end{array}$ & $\begin{array}{l}-0.003 \\
(0.003)\end{array}$ \\
\hline Haircut (PV) & & & $\begin{array}{l}0.478^{* * *} \\
0.087)\end{array}$ & & $\begin{array}{l}0.248^{* *} \\
0.119)\end{array}$ & 0.068 & $\begin{array}{l}3.748^{* * *} \\
(1.161)\end{array}$ & $\begin{array}{l}0.038^{* * *} \\
(0.009)\end{array}$ \\
\hline Debt restruct. (log) & & & $\begin{array}{l}0.034^{* *} \\
0.014)\end{array}$ & & $\begin{array}{l}0.062^{* * *} \\
0.015)\end{array}$ & 0.125 & $\begin{array}{l}0.847^{* * *} \\
(0.175)\end{array}$ & $\begin{array}{l}0.003^{*} \\
(0.001)\end{array}$ \\
\hline Bond restructuring & & & $\begin{array}{l}0.119 \\
0.083)\end{array}$ & & $\begin{array}{l}0.022 \\
0.098)\end{array}$ & 0.023 & $\begin{array}{l}0.871^{*} \\
(0.496)\end{array}$ & $\begin{array}{l}0.014^{* *} \\
(0.006)\end{array}$ \\
\hline Corporate high yield & & & & $\begin{array}{l}-4.433^{* * *} \\
(0.862)\end{array}$ & $\begin{array}{l}-2.493^{*} \\
1.386)\end{array}$ & -0.071 & $\begin{array}{l}-28.630^{* * * *} \\
(9.921)\end{array}$ & $\begin{array}{l}-0.216^{* *} \\
(0.107)\end{array}$ \\
\hline GDP per capita (log) & & & & & $\begin{array}{l}-0.007 \\
0.027)\end{array}$ & -0.008 & $\begin{array}{l}-0.027 \\
(0.222)\end{array}$ & $\begin{array}{l}0.004^{* *} \\
(0.002)\end{array}$ \\
\hline Secondary market & & & & & $\begin{array}{l}-0.099 \\
0.070)\end{array}$ & -0.083 & $\begin{array}{l}-0.975^{* *} \\
(0.454)\end{array}$ & $\begin{array}{l}-0.017^{* * *} \\
(0.006)\end{array}$ \\
\hline US, UK/Total ext. debt & & & & & $\begin{array}{l}0.256^{* * *} \\
0.078)\end{array}$ & 0.079 & $\begin{array}{l}2.728^{* * *} \\
(0.769)\end{array}$ & $\begin{array}{l}0.025^{* * *} \\
(0.008)\end{array}$ \\
\hline Constant & & & & & & & $\begin{array}{l}-0.657 \\
(2.677) \\
\end{array}$ & \\
\hline $\begin{array}{l}\text { AUROC } \\
\text { s.e. }\end{array}$ & $\begin{array}{l}0.772 \\
0.045\end{array}$ & $\begin{array}{l}0.643 \\
0.057\end{array}$ & $\begin{array}{l}0.780 \\
0.047\end{array}$ & $\begin{array}{l}0.758 \\
0.047\end{array}$ & $\begin{array}{l}0.863 \\
0.036\end{array}$ & & & \\
\hline Pseudo R2 & 0.18 & 0.06 & 0.17 & 0.14 & 0.33 & & 0.28 & 0.28 \\
\hline Log Likelihood & -67.07 & -76.89 & -67.58 & -69.80 & -55.03 & & -104.68 & -5.04 \\
\hline Obs & 174 & 174 & 174 & 174 & 174 & & 174 & 172 \\
\hline Chi2 & 32.61 & 8.67 & 24.77 & 26.32 & 95.66 & & 183.63 & 107.89 \\
\hline $\mathrm{p}>$ Chi2 & 0.00 & 0.01 & 0.00 & 0.00 & 0.00 & & 0.00 & 0.00 \\
\hline
\end{tabular}


Table 3: Robustness checks (I)

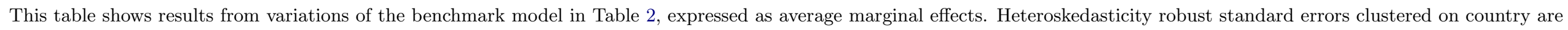

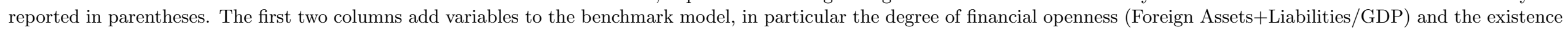

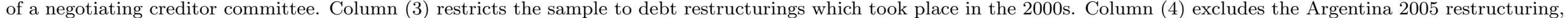

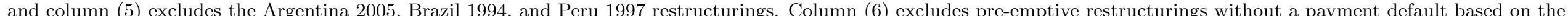

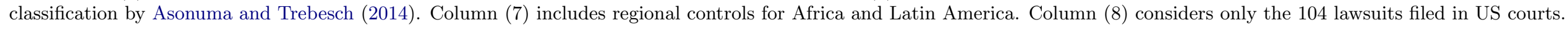

\begin{tabular}{|c|c|c|c|c|c|c|c|c|}
\hline & (1) & (2) & (3) & $(4)$ & $(5)$ & $\overline{(6)}$ & $\overline{(7)}$ & $(8)$ \\
\hline & $\begin{array}{l}\text { Financial } \\
\text { openness }\end{array}$ & $\begin{array}{l}\text { With creditor } \\
\text { committee }\end{array}$ & $\begin{array}{l}\text { Post-2000 (af- } \\
\text { ter Elliott) }\end{array}$ & Exclude ARG & $\begin{array}{l}\text { Exclude } \\
\text { ARG, BRA, } \\
\text { PER }\end{array}$ & $\begin{array}{l}\text { Exclude pre- } \\
\text { emptive deals }\end{array}$ & $\begin{array}{l}\text { Region fixed } \\
\text { effects }\end{array}$ & $\begin{array}{l}\text { US lawsuits } \\
\text { only }\end{array}$ \\
\hline Post Allied ('85-'91) & $\begin{array}{l}-0.048 \\
(0.099)\end{array}$ & $\begin{array}{l}-0.079 \\
(0.092)\end{array}$ & & $\begin{array}{l}-0.035 \\
(0.093)\end{array}$ & $\begin{array}{l}-0.042 \\
(0.094)\end{array}$ & $\begin{array}{l}-0.109 \\
(0.102)\end{array}$ & $\begin{array}{l}-0.024 \\
(0.097)\end{array}$ & $\begin{array}{l}-0.124 \\
(0.086)\end{array}$ \\
\hline Post Weltover ('92-'94) & $\begin{array}{l}0.100 \\
(0.141)\end{array}$ & $\begin{array}{l}0.050 \\
(0.124)\end{array}$ & & $\begin{array}{l}0.093 \\
(0.131)\end{array}$ & $\begin{array}{l}0.073 \\
(0.134)\end{array}$ & $\begin{array}{l}-0.015 \\
(0.150)\end{array}$ & $\begin{array}{l}0.102 \\
(0.124)\end{array}$ & $\begin{array}{l}-0.047 \\
(0.121)\end{array}$ \\
\hline Post CIBC ('95-'99) & $\begin{array}{l}0.040 \\
(0.142)\end{array}$ & $\begin{array}{l}-0.001 \\
(0.122)\end{array}$ & & $\begin{array}{l}0.023 \\
(0.134)\end{array}$ & $\begin{array}{l}-0.002 \\
(0.136)\end{array}$ & $\begin{array}{l}-0.111 \\
(0.147)\end{array}$ & $\begin{array}{l}0.025 \\
(0.126)\end{array}$ & $\begin{array}{l}-0.137 \\
(0.125)\end{array}$ \\
\hline Post Elliott ('00-'10) & $\begin{array}{l}0.031 \\
(0.151)\end{array}$ & $\begin{array}{l}-0.027 \\
(0.129)\end{array}$ & & $\begin{array}{l}0.028 \\
(0.140)\end{array}$ & $\begin{array}{l}0.001 \\
(0.141)\end{array}$ & $\begin{array}{l}-0.047 \\
(0.153)\end{array}$ & $\begin{array}{l}0.026 \\
(0.133)\end{array}$ & $\begin{array}{l}-0.110 \\
(0.136)\end{array}$ \\
\hline Gov. effectiveness & $\begin{array}{l}-0.097^{* *} \\
(0.041)\end{array}$ & $\begin{array}{l}-0.078^{* *} \\
(0.034)\end{array}$ & $\begin{array}{l}-0.329^{*} \\
(0.199)\end{array}$ & $\begin{array}{l}-0.101^{* * *} \\
(0.039)\end{array}$ & $\begin{array}{l}-0.102^{* * *} \\
(0.039)\end{array}$ & $\begin{array}{l}-0.098^{* *} \\
(0.044)\end{array}$ & $\begin{array}{l}-0.142^{* * *} \\
(0.054)\end{array}$ & $\begin{array}{l}-0.049 \\
(0.034)\end{array}$ \\
\hline Openness to trade & & $\begin{array}{l}0.120^{* *} \\
(0.052)\end{array}$ & $\begin{array}{l}0.107 \\
(0.256)\end{array}$ & $\begin{array}{l}0.135^{* *} \\
(0.056)\end{array}$ & $\begin{array}{l}0.136^{* *} \\
(0.057)\end{array}$ & $\begin{array}{l}0.129^{* *} \\
(0.062)\end{array}$ & $\begin{array}{l}0.112^{* *} \\
(0.053)\end{array}$ & $\begin{array}{l}0.102^{* *} \\
(0.040)\end{array}$ \\
\hline Haircut (PV) & $\begin{array}{l}0.217^{*} \\
(0.123)\end{array}$ & $\begin{array}{l}0.316^{* * *} \\
(0.105)\end{array}$ & $\begin{array}{l}0.727^{*} \\
(0.427)\end{array}$ & $\begin{array}{l}0.220^{*} \\
(0.125)\end{array}$ & $\begin{array}{l}0.248^{* *} \\
(0.119)\end{array}$ & $\begin{array}{l}0.276^{* *} \\
(0.139)\end{array}$ & $\begin{array}{l}0.233^{* *} \\
(0.117)\end{array}$ & $\begin{array}{l}0.247^{* *} \\
(0.121)\end{array}$ \\
\hline Debt restruct. (log) & $\begin{array}{l}0.054^{* * *} \\
(0.014)\end{array}$ & $\begin{array}{l}0.065^{* * *} \\
(0.016)\end{array}$ & $\begin{array}{l}0.142^{* *} \\
(0.059)\end{array}$ & $\begin{array}{l}0.059^{* * *} \\
(0.016)\end{array}$ & $\begin{array}{l}0.062^{* * *} \\
(0.015)\end{array}$ & $\begin{array}{l}0.054^{* * *} \\
(0.016)\end{array}$ & $\begin{array}{l}0.057^{* * *} \\
(0.015)\end{array}$ & $\begin{array}{l}0.053^{* * *} \\
(0.015)\end{array}$ \\
\hline Bond restructuring & $\begin{array}{l}0.003 \\
(0.095)\end{array}$ & & $\begin{array}{l}0.191 \\
(0.238)\end{array}$ & $\begin{array}{l}0.002 \\
(0.103)\end{array}$ & $\begin{array}{l}0.022 \\
(0.098)\end{array}$ & $\begin{array}{l}-0.058 \\
(0.104)\end{array}$ & $\begin{array}{l}0.017 \\
(0.092)\end{array}$ & $\begin{array}{l}-0.000 \\
(0.082)\end{array}$ \\
\hline Corporate high yield & $\begin{array}{l}-2.436 \\
(1.526)\end{array}$ & $\begin{array}{l}-2.416^{*} \\
(1.358)\end{array}$ & $\begin{array}{l}-12.322^{*} \\
(6.369)\end{array}$ & $\begin{array}{l}-2.235 \\
(1.370)\end{array}$ & $\begin{array}{l}-2.495^{*} \\
(1.387)\end{array}$ & $\begin{array}{l}-3.286^{* *} \\
(1.471)\end{array}$ & $\begin{array}{l}-2.403^{*} \\
(1.331)\end{array}$ & $\begin{array}{l}-3.067^{* *} \\
(1.269)\end{array}$ \\
\hline GDP per capita (log) & $\begin{array}{l}-0.008 \\
(0.027)\end{array}$ & $\begin{array}{l}0.017 \\
(0.020)\end{array}$ & $\begin{array}{l}0.051 \\
(0.072)\end{array}$ & $\begin{array}{l}-0.008 \\
(0.027)\end{array}$ & $\begin{array}{l}-0.007 \\
(0.027)\end{array}$ & $\begin{array}{l}-0.001 \\
(0.028)\end{array}$ & $\begin{array}{l}-0.014 \\
(0.032)\end{array}$ & $\begin{array}{l}0.008 \\
(0.022)\end{array}$ \\
\hline Secondary market & $\begin{array}{l}-0.091 \\
(0.072)\end{array}$ & $\begin{array}{l}-0.121^{*} \\
(0.063)\end{array}$ & $\begin{array}{l}-0.652^{*} \\
(0.333)\end{array}$ & $\begin{array}{l}-0.095 \\
(0.072)\end{array}$ & $\begin{array}{l}-0.100 \\
(0.070)\end{array}$ & $\begin{array}{l}-0.023 \\
(0.071)\end{array}$ & $\begin{array}{l}-0.112 \\
(0.069)\end{array}$ & $\begin{array}{l}-0.043 \\
(0.060)\end{array}$ \\
\hline US, UK/Total ext. debt & $\begin{array}{l}0.217^{* *} \\
(0.086)\end{array}$ & $\begin{array}{l}0.277^{* * *} \\
(0.077)\end{array}$ & $\begin{array}{l}1.196^{* * *} \\
(0.397)\end{array}$ & $\begin{array}{l}0.255^{* * *} \\
(0.077)\end{array}$ & $\begin{array}{l}0.256^{* * *} \\
(0.078)\end{array}$ & $\begin{array}{l}0.236^{* * *} \\
(0.080)\end{array}$ & $\begin{array}{l}0.185^{* *} \\
(0.094)\end{array}$ & $\begin{array}{l}0.226^{* * *} \\
(0.069)\end{array}$ \\
\hline Financial openness & $\begin{array}{l}0.045^{* *} \\
(0.018)\end{array}$ & & & & & & & \\
\hline Creditor committee & & $\begin{array}{l}-0.100 \\
(0.087)\end{array}$ & & & & & & \\
\hline Region fixed effects & & & & & & & Yes & \\
\hline AUROC & 0.859 & 0.882 & 0.832 & 0.864 & 0.863 & 0.852 & 0.873 & 0.840 \\
\hline s.e. & 0.036 & 0.034 & 0.042 & 0.036 & 0.036 & 0.038 & 0.035 & 0.044 \\
\hline Pseudo R2 & 0.31 & 0.37 & 0.51 & 0.31 & 0.32 & 0.34 & 0.35 & 0.34 \\
\hline Log Likelihood & -53.37 & -50.38 & -7.93 & -54.72 & -55.04 & -48.99 & -53.10 & -44.99 \\
\hline Obs & 162 & 173 & 24 & 173 & 174 & 152 & 174 & 174 \\
\hline Chi2 & 71.87 & 78.03 & 26.21 & 80.64 & 95.89 & 89.65 & 85.09 & 48.24 \\
\hline $\mathrm{p}>\mathrm{Chi} 2$ & 0.00 & 0.00 & 0.00 & 0.00 & 0.00 & 0.00 & 0.00 & 0.00 \\
\hline
\end{tabular}

Significance levels indicated by ${ }^{*} p<0.1,{ }^{* *} p<0.05,{ }^{* * *} p<0.01$ 
Table 4: Robustness checks (II)

This table shows the results from model (9) with interactions of the main variables of interest with the debt volume restructured in each case. Heteroskedasticity robust standard errors clustered on country are reported in parentheses. Consistent with the results in the other tables, the results are expressed as average marginal effects, thus the coefficient on the interaction term is not explicitly included. Note that the average marginal effects remain consistent with the findings in the previous non-interaction models. For a visual representation of the results, see figure 4 .

\begin{tabular}{|c|c|c|c|c|c|}
\hline & (1) & $(2)$ & $(3)$ & $(4)$ & $(5)$ \\
\hline & $\begin{array}{l}\text { Openness to } \\
\text { trade }\end{array}$ & $\begin{array}{l}\text { Gov. effec- } \\
\text { tiveness }\end{array}$ & Haircut (PV) & $\begin{array}{l}\text { Bond restruc- } \\
\text { turing }\end{array}$ & $\begin{array}{l}\text { Corporate } \\
\text { high yield }\end{array}$ \\
\hline Post Allied ('85-'91) & $\begin{array}{l}-0.043 \\
(0.094)\end{array}$ & $\begin{array}{l}-0.043 \\
(0.092)\end{array}$ & $\begin{array}{l}-0.020 \\
(0.091)\end{array}$ & $\begin{array}{l}-0.048 \\
(0.096)\end{array}$ & $\begin{array}{l}-0.023 \\
(0.095)\end{array}$ \\
\hline Post Weltover ('92-'94) & $\begin{array}{l}0.069 \\
(0.135)\end{array}$ & $\begin{array}{l}0.071 \\
(0.135)\end{array}$ & $\begin{array}{l}0.091 \\
(0.130)\end{array}$ & $\begin{array}{l}0.076 \\
(0.137)\end{array}$ & $\begin{array}{l}0.092 \\
(0.134)\end{array}$ \\
\hline Post CIBC ('95-'99) & $\begin{array}{l}-0.003 \\
(0.136)\end{array}$ & $\begin{array}{l}-0.003 \\
(0.136)\end{array}$ & $\begin{array}{l}0.025 \\
(0.128)\end{array}$ & $\begin{array}{l}-0.002 \\
(0.139)\end{array}$ & $\begin{array}{l}0.018 \\
(0.135)\end{array}$ \\
\hline Post Elliott ('00-'10) & $\begin{array}{l}0.001 \\
(0.141)\end{array}$ & $\begin{array}{l}0.001 \\
(0.141)\end{array}$ & $\begin{array}{l}0.011 \\
(0.136)\end{array}$ & $\begin{array}{l}-0.001 \\
(0.146)\end{array}$ & $\begin{array}{l}0.029 \\
(0.140)\end{array}$ \\
\hline Gov. effectiveness & $\begin{array}{l}-0.105^{* * *} \\
(0.041)\end{array}$ & $\begin{array}{l}-0.101^{* * *} \\
(0.038)\end{array}$ & $\begin{array}{l}-0.082^{* *} \\
(0.036)\end{array}$ & $\begin{array}{l}-0.109^{* * *} \\
(0.037)\end{array}$ & $\begin{array}{l}-0.091^{* *} \\
(0.039)\end{array}$ \\
\hline Openness to trade & $\begin{array}{l}0.126^{* *} \\
(0.056)\end{array}$ & $\begin{array}{l}0.138^{* *} \\
(0.062)\end{array}$ & $\begin{array}{l}0.122^{* *} \\
(0.058)\end{array}$ & $\begin{array}{l}0.134^{* *} \\
(0.058)\end{array}$ & $\begin{array}{l}0.131^{* *} \\
(0.054)\end{array}$ \\
\hline Haircut (PV) & $\begin{array}{l}0.247^{* *} \\
(0.120)\end{array}$ & $\begin{array}{l}0.247^{* *} \\
(0.120)\end{array}$ & $\begin{array}{l}0.273^{* *} \\
(0.111)\end{array}$ & $\begin{array}{l}0.274^{* *} \\
(0.127)\end{array}$ & $\begin{array}{l}0.228^{*} \\
(0.121)\end{array}$ \\
\hline Debt restruct. (log) & $\begin{array}{l}0.061^{* * * *} \\
(0.015)\end{array}$ & $\begin{array}{l}0.062^{* * * *} \\
(0.016)\end{array}$ & $\begin{array}{l}0.064^{* * * *} \\
(0.014)\end{array}$ & $\begin{array}{l}0.062^{* * *} \\
(0.016)\end{array}$ & $\begin{array}{l}0.063^{* * *} \\
(0.015)\end{array}$ \\
\hline Bond restructuring & $\begin{array}{l}0.024 \\
(0.098)\end{array}$ & $\begin{array}{l}0.023 \\
(0.097)\end{array}$ & $\begin{array}{l}0.005 \\
(0.097)\end{array}$ & $\begin{array}{l}0.031 \\
(0.099)\end{array}$ & $\begin{array}{l}0.022 \\
(0.097)\end{array}$ \\
\hline Corporate high yield & $\begin{array}{l}-2.511^{*} \\
(1.365)\end{array}$ & $\begin{array}{c}-2.505^{*} \\
(1.388)\end{array}$ & $\begin{array}{l}-2.227 \\
(1.398)\end{array}$ & $\begin{array}{l}-2.246 \\
(1.379)\end{array}$ & $\begin{array}{c}-2.482^{*} \\
(1.361)\end{array}$ \\
\hline GDP per capita (log) & $\begin{array}{l}-0.007 \\
(0.027)\end{array}$ & $\begin{array}{l}-0.008 \\
(0.030)\end{array}$ & $\begin{array}{l}-0.012 \\
(0.025)\end{array}$ & $\begin{array}{l}-0.006 \\
(0.027)\end{array}$ & $\begin{array}{l}-0.011 \\
(0.025)\end{array}$ \\
\hline Secondary market & $\begin{array}{l}-0.100 \\
(0.069)\end{array}$ & $\begin{array}{l}-0.100 \\
(0.069)\end{array}$ & $\begin{array}{l}-0.107 \\
(0.070)\end{array}$ & $\begin{array}{l}-0.100 \\
(0.067)\end{array}$ & $\begin{array}{l}-0.116 \\
(0.074)\end{array}$ \\
\hline US, UK/Total ext. debt & $\begin{array}{l}0.256^{* * *} \\
(0.079)\end{array}$ & $\begin{array}{l}0.257^{* * *} \\
(0.077)\end{array}$ & $\begin{array}{l}0.252^{* * *} \\
(0.073)\end{array}$ & $\begin{array}{l}0.252^{* * *} \\
(0.076)\end{array}$ & $\begin{array}{l}0.264^{* * *} \\
(0.076)\end{array}$ \\
\hline AUROC & 0.863 & 0.863 & 0.870 & 0.866 & 0.864 \\
\hline s.e. & 0.035 & 0.036 & 0.037 & 0.035 & 0.036 \\
\hline Pseudo R2 & 0.33 & 0.32 & 0.35 & 0.33 & 0.33 \\
\hline Log Likelihood & -54.97 & -55.04 & -53.16 & -54.66 & -54.46 \\
\hline Obs & 174 & 174 & 174 & 174 & 174 \\
\hline Chi2 & 93.47 & 100.04 & 113.82 & 98.15 & 99.34 \\
\hline $\mathrm{p}>$ Chi2 & 0.00 & 0.00 & 0.00 & 0.00 & 0.00 \\
\hline
\end{tabular}


Table 5: Instrumental variable regressions

The table shows IV regression results using $\ln (\mathrm{debt} / \mathrm{GDP})$ as an instrument for haircut size. The first column shows the first stage regression on the determinants of haircuts. The second and third column show second-stage results on litigation occurrence using an OLS and probit model, respectively. The sample size is somewhat smaller due to the lack of data on debt/GDP for some countries during the 1980s and early 1990s, but all our main results above hold in this subsample as well. Heteroskedasticity robust standard errors clustered on country are reported in parentheses.

\begin{tabular}{|c|c|c|c|}
\hline & $(1)$ & $(2)$ & $(3)$ \\
\hline \multirow[t]{3}{*}{ Instrument: } & \multicolumn{3}{|c|}{ Debt/GDP } \\
\hline & \multirow{2}{*}{$\begin{array}{l}\text { 1st stage: } \\
\text { Haircut }\end{array}$} & \multicolumn{2}{|c|}{ 2nd stage: } \\
\hline & & OLS & Probit \\
\hline Post Allied ('85-'91) & $\begin{array}{l}0.111^{* * *} \\
(0.034)\end{array}$ & $\begin{array}{c}-0.153 \\
(0.096)\end{array}$ & $\begin{array}{l}-0.115 \\
(0.106)\end{array}$ \\
\hline Post Weltover ('92-'94) & $\begin{array}{l}0.346^{* * *} \\
(0.079)\end{array}$ & $\begin{array}{c}-0.083 \\
(0.220)\end{array}$ & $\begin{array}{l}-0.096 \\
(0.172)\end{array}$ \\
\hline Post CIBC ('95-'99) & $\begin{array}{l}0.429^{* * *} \\
(0.079)\end{array}$ & $\begin{array}{l}-0.180 \\
(0.195)\end{array}$ & $\begin{array}{l}-0.215 \\
(0.173)\end{array}$ \\
\hline Post Elliott ('00-'10) & $\begin{array}{l}0.640 * * * \\
(0.083)\end{array}$ & $\begin{array}{l}-0.265 \\
(0.265)\end{array}$ & $\begin{array}{l}-0.300 \\
(0.213)\end{array}$ \\
\hline Openness to trade & $\begin{array}{l}-0.111^{* *} \\
(0.051)\end{array}$ & $\begin{array}{l}0.174^{* *} \\
(0.079)\end{array}$ & $\begin{array}{l}0.154^{* * *} \\
(0.058)\end{array}$ \\
\hline Haircut (PV) & & $\begin{array}{l}0.924^{* * *} \\
(0.318)\end{array}$ & $\begin{array}{l}0.693^{* * *} \\
(0.258)\end{array}$ \\
\hline Gov. effectiveness & $\begin{array}{l}-0.058^{* *} \\
(0.023)\end{array}$ & $\begin{array}{l}-0.036 \\
(0.049)\end{array}$ & $\begin{array}{l}-0.069 \\
(0.044)\end{array}$ \\
\hline Debt restruct. (log) & $\begin{array}{l}-0.029^{* *} \\
(0.011)\end{array}$ & $\begin{array}{l}0.076^{* * *} \\
(0.021)\end{array}$ & $\begin{array}{l}0.070^{* * *} \\
(0.017)\end{array}$ \\
\hline Bond restructuring & $\begin{array}{l}-0.321^{* * *} \\
(0.065)\end{array}$ & $\begin{array}{l}0.127 \\
(0.202)\end{array}$ & $\begin{array}{l}0.162 \\
(0.142)\end{array}$ \\
\hline Corporate high yield & $\begin{array}{l}1.785^{* *} \\
(0.859)\end{array}$ & $\begin{array}{c}-2.899^{*} \\
(1.670)\end{array}$ & $\begin{array}{l}-3.297^{* *} \\
(1.409)\end{array}$ \\
\hline GDP per capita (log) & $\begin{array}{c}-0.027^{*} \\
(0.014)\end{array}$ & $\begin{array}{l}0.011 \\
(0.036)\end{array}$ & $\begin{array}{l}0.009 \\
(0.028)\end{array}$ \\
\hline Secondary market & $\begin{array}{l}0.060 \\
(0.046)\end{array}$ & $\begin{array}{l}-0.101 \\
(0.083)\end{array}$ & $\begin{array}{l}-0.109 \\
(0.074)\end{array}$ \\
\hline US, UK/Total ext. debt & $\begin{array}{l}0.014 \\
(0.063)\end{array}$ & $\begin{array}{l}0.221^{* *} \\
(0.107)\end{array}$ & $\begin{array}{l}0.214^{* * *} \\
(0.079)\end{array}$ \\
\hline Debt/GDP (Log, Lag) & $\begin{array}{l}0.178^{* * *} \\
(0.026)\end{array}$ & & \\
\hline Constant & $\begin{array}{l}0.228 \\
(0.192) \\
\end{array}$ & $\begin{array}{l}0.049 \\
(0.372) \\
\end{array}$ & \\
\hline Anderson Rubin Wald & 8.45 & & \\
\hline p-Value & 0.01 & & \\
\hline Cragg-Donald F & 43.74 & & \\
\hline Kleibergen-Paap Wald rk F & 46.96 & & \\
\hline Obs & 154 & 154 & 154 \\
\hline
\end{tabular}


Table 6: Case list: Litigation across sovereign debt restructurings

This table shows our new sovereign debt litigation data matched to the list of restructurings and haircuts by Cruces and Trebesch (2013) (Data in columns designated with * are also taken from the Cruces/Trebesch dataset). All amounts are in 2005 USD.

\begin{tabular}{|c|c|c|c|c|c|c|}
\hline Country & Year* & $\begin{array}{r}\text { Restructured debt* } \\
\text { (USD m) }\end{array}$ & Haircut* & Litigation & No. cases & $\begin{array}{r}\text { Litigation volume } \\
\text { (USD m) }\end{array}$ \\
\hline Albania & 1995 & 611.2 & $80.4 \%$ & no & 0 & - \\
\hline Algeria & 1992 & $1,897.3$ & $8.7 \%$ & no & 0 & - \\
\hline Algeria & 1996 & $3,833.8$ & $23.5 \%$ & no & 0 & - \\
\hline Argentina & 1985 & $15,893.3$ & $30.3 \%$ & no & 0 & - \\
\hline Argentina & 1987 & $45,290.1$ & $21.7 \%$ & yes & 2 & 2.0 \\
\hline Argentina & 1993 & $36,218.7$ & $32.5 \%$ & no & 0 & - \\
\hline Argentina & 2005 & $60,572.0$ & $76.8 \%$ & yes & 41 & $2,855.0$ \\
\hline Belize & 2007 & 487.7 & $23.7 \%$ & no & 0 & - \\
\hline Bolivia & 1988 & 701.3 & $92.7 \%$ & no & 0 & - \\
\hline Bolivia & 1993 & 217.5 & $76.5 \%$ & yes & 1 & 1.2 \\
\hline Bosnia and Herzegovina & 1997 & $1,531.3$ & $89.6 \%$ & no & 0 & - \\
\hline Brazil & 1983 & $7,637.6$ & $-9.8 \%$ & no & 0 & - \\
\hline Brazil & 1984 & $8,028.5$ & $1.7 \%$ & no & 0 & - \\
\hline Brazil & 1986 & $10,497.8$ & $19.2 \%$ & no & 0 & - \\
\hline Brazil & 1988 & $92,067.8$ & $18.4 \%$ & no & 0 & - \\
\hline Brazil & 1992 & $11,937.0$ & $27.0 \%$ & no & 0 & - \\
\hline Brazil & 1994 & $53,871.8$ & $29.3 \%$ & yes & 1 & $1,743.5$ \\
\hline Bulgaria & 1994 & $9,851.0$ & $56.3 \%$ & yes & 1 & 14.9 \\
\hline Cameroon & 2003 & 844.1 & $85.5 \%$ & yes & 2 & 13.6 \\
\hline Chile & 1983 & $3,721.0$ & $0.7 \%$ & no & 0 & - \\
\hline Chile & 1984 & $1,921.8$ & $8.4 \%$ & no & 0 & - \\
\hline Chile & 1986 & $9,452.9$ & $31.7 \%$ & no & 0 & - \\
\hline Chile & 1987 & $9,055.0$ & $14.3 \%$ & no & 0 & - \\
\hline Chile & 1990 & $8,936.8$ & $17.0 \%$ & no & 0 & - \\
\hline Congo, Dem. Rep. & 1980 & 832.4 & $29.6 \%$ & no & 0 & - \\
\hline Congo, Dem. Rep. & 1983 & 99.5 & $38.2 \%$ & no & 0 & - \\
\hline Congo, Dem. Rep. & 1984 & 106.0 & $30.1 \%$ & no & 0 & - \\
\hline Congo, Dem. Rep. & 1985 & 97.9 & $37.0 \%$ & no & 0 & - \\
\hline Congo, Dem. Rep. & 1986 & 102.3 & $35.4 \%$ & no & 0 & - \\
\hline Congo, Dem. Rep. & 1987 & 93.6 & $26.8 \%$ & no & 0 & - \\
\hline Congo, Dem. Rep. & 1989 & 87.1 & $50.6 \%$ & yes & 1 & 12.3 \\
\hline Congo, Rep. & 1988 & 321.7 & $42.3 \%$ & yes & 1 & - \\
\hline Congo, Rep. & 2007 & $1,984.7$ & $90.8 \%$ & yes & 7 & 148.5 \\
\hline Costa Rica & 1983 & $1,044.8$ & $39.4 \%$ & yes & 2 & 77.5 \\
\hline Costa Rica & 1985 & 706.4 & $35.6 \%$ & no & 0 & - \\
\hline Costa Rica & 1990 & $1,904.6$ & $71.9 \%$ & no & 0 & - \\
\hline Cote d'Ivoire & 1998 & $7,530.0$ & $62.8 \%$ & yes & 1 & 9.3 \\
\hline Cote d'Ivoire & 2010 & $2,672.2$ & $55.2 \%$ & no & 0 & - \\
\hline Croatia & 1996 & $1,027.9$ & $11.0 \%$ & no & 0 & - \\
\hline Cuba & 1983 & 223.0 & $42.9 \%$ & no & 0 & - \\
\hline Cuba & 1984 & 170.6 & $44.2 \%$ & no & 0 & - \\
\hline Cuba & 1985 & 144.5 & $49.5 \%$ & no & 0 & - \\
\hline Dominica & 2004 & 148.6 & $54.0 \%$ & yes & 1 & 11.7 \\
\hline Dominican Republic & 1986 & $1,295.1$ & $49.9 \%$ & no & 0 & - \\
\hline Dominican Republic & 1994 & $1,353.7$ & $50.5 \%$ & no & 0 & - \\
\hline Dominican Republic & 2005 & $1,280.0$ & $8.0 \%$ & no & 0 & - \\
\hline Ecuador & 1983 & $1,664.1$ & $6.3 \%$ & no & 0 & - \\
\hline Ecuador & 1984 & 579.9 & $5.7 \%$ & no & 0 & - \\
\hline Ecuador & 1985 & $6,781.1$ & $15.4 \%$ & no & 0 & - \\
\hline Ecuador & 1995 & $8,747.0$ & $42.2 \%$ & yes & 4 & 44.5 \\
\hline Ecuador & 2000 & $7,526.4$ & $38.3 \%$ & yes & 2 & 5.6 \\
\hline Ecuador & 2009 & $2,934.5$ & $67.7 \%$ & no & 0 & - \\
\hline Ethiopia & 1996 & 270.8 & $92.0 \%$ & no & 0 & - \\
\hline Gabon & 1987 & 59.8 & $7.9 \%$ & no & 0 & - \\
\hline Gabon & 1994 & 232.9 & $16.2 \%$ & no & 0 & - \\
\hline Gambia, The & 1988 & 28.2 & $49.3 \%$ & no & 0 & 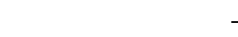 \\
\hline Grenada & 2005 & 210.0 & $33.9 \%$ & yes & 1 & 20.3 \\
\hline Guinea & 1988 & 63.8 & $26.1 \%$ & no & 0 & - \\
\hline Guinea & 1998 & 151.5 & $87.0 \%$ & no & 0 & \\
\hline
\end{tabular}


Table 6: Case list: Litigation across sovereign debt restructurings (continued)

\begin{tabular}{|c|c|c|c|c|c|c|}
\hline Country & Year* & $\begin{array}{r}\text { Restructured debt* } \\
\text { (USD m) }\end{array}$ & Haircut* $^{*}$ & Litigation & No. cases & $\begin{array}{r}\text { Litigation volume } \\
\text { (USD m) }\end{array}$ \\
\hline Guyana & 1992 & 121.1 & $89.2 \%$ & yes & 1 & 18.4 \\
\hline Guyana & 1999 & 64.3 & $91.0 \%$ & yes & 1 & 12.0 \\
\hline Honduras & 1989 & 188.4 & $73.2 \%$ & no & 0 & - \\
\hline Honduras & 2001 & 14.3 & $82.0 \%$ & no & 0 & - \\
\hline Iraq & 2006 & $17,181.8$ & $89.4 \%$ & yes & 10 & 168.9 \\
\hline Jamaica & 1978 & 154.0 & $2.2 \%$ & no & 0 & - \\
\hline Jamaica & 1979 & 336.4 & $3.5 \%$ & no & 0 & - \\
\hline Jamaica & 1981 & 168.6 & $15.2 \%$ & no & 0 & - \\
\hline Jamaica & 1984 & 273.4 & $18.1 \%$ & no & 0 & - \\
\hline Jamaica & 1985 & 592.4 & $31.7 \%$ & yes & 1 & 16.1 \\
\hline Jamaica & 1987 & 437.3 & $32.8 \%$ & no & 0 & - \\
\hline Jamaica & 1990 & 456.9 & $44.0 \%$ & no & 0 & - \\
\hline Jordan & 1993 & $1,639.5$ & $54.6 \%$ & no & 0 & - \\
\hline Kenya & 1998 & 106.0 & $45.7 \%$ & no & 0 & - \\
\hline Liberia & 1982 & 53.5 & $35.7 \%$ & no & 0 & - \\
\hline Liberia & 2009 & $1,175.5$ & $97.0 \%$ & yes & 9 & 46.4 \\
\hline Macedonia, FYR & 1997 & 269.7 & $34.6 \%$ & no & 0 & - \\
\hline Madagascar & 1981 & 278.4 & $19.0 \%$ & no & 0 & - \\
\hline Madagascar & 1984 & 323.1 & $41.3 \%$ & no & 0 & - \\
\hline Madagascar & 1987 & 92.1 & $13.7 \%$ & no & 0 & - \\
\hline Madagascar & 1990 & 67.4 & $52.7 \%$ & no & 0 & - \\
\hline Malawi & 1983 & 97.8 & $28.5 \%$ & no & 0 & - \\
\hline Malawi & 1988 & 51.9 & $39.2 \%$ & no & 0 & - \\
\hline Mauritania & 1996 & 63.5 & $90.0 \%$ & no & 0 & - \\
\hline Mexico & 1983 & $32,252.0$ & $-0.2 \%$ & no & 0 & - \\
\hline Mexico & 1985 & $78,182.2$ & $3.8 \%$ & no & 0 & - \\
\hline Mexico & 1987 & $80,253.2$ & $18.1 \%$ & no & 0 & - \\
\hline Mexico & 1988 & $5,442.5$ & $56.3 \%$ & no & 0 & - \\
\hline Mexico & 1990 & $74,725.8$ & $30.5 \%$ & no & 0 & - \\
\hline Moldova & 2002 & 43.3 & $36.9 \%$ & no & 0 & - \\
\hline Moldova & 2004 & 118.7 & $56.3 \%$ & no & 0 & - \\
\hline Morocco & 1986 & 846.6 & $23.5 \%$ & no & 0 & - \\
\hline Morocco & 1987 & $3,750.3$ & $21.3 \%$ & no & 0 & - \\
\hline Morocco & 1990 & $4,403.7$ & $40.3 \%$ & no & 0 & - \\
\hline Mozambique & 1991 & 165.2 & $90.0 \%$ & no & 0 & - \\
\hline Mozambique & 2007 & 144.6 & $91.0 \%$ & no & 0 & - \\
\hline Nicaragua & 1980 & $1,205.1$ & $26.1 \%$ & no & 0 & - \\
\hline Nicaragua & 1981 & 363.6 & $48.5 \%$ & no & 0 & - \\
\hline Nicaragua & 1982 & 178.3 & $56.3 \%$ & no & 0 & - \\
\hline Nicaragua & 1984 & 240.2 & $41.7 \%$ & no & 0 & - \\
\hline Nicaragua & 1995 & $1,341.9$ & $92.0 \%$ & yes & 4 & 299.1 \\
\hline Nicaragua & 2007 & $1,323.1$ & $95.5 \%$ & yes & 1 & 8.8 \\
\hline Niger & 1984 & 44.7 & $37.4 \%$ & no & 0 & - \\
\hline Niger & 1986 & 81.8 & $45.8 \%$ & no & 0 & - \\
\hline Niger & 1991 & 147.8 & $82.0 \%$ & no & 0 & - \\
\hline Nigeria & 1983 & $3,319.6$ & $1.6 \%$ & yes & 3 & 144.8 \\
\hline Nigeria & 1984 & $1,532.5$ & $-2.8 \%$ & no & 0 & - \\
\hline Nigeria & 1987 & $6,520.0$ & $19.3 \%$ & no & 0 & - \\
\hline Nigeria & 1988 & $1,798.4$ & $41.5 \%$ & no & 0 & - \\
\hline Nigeria & 1989 & $8,318.5$ & $30.1 \%$ & no & 0 & - \\
\hline Nigeria & 1991 & $7,835.4$ & $40.1 \%$ & no & 0 & - \\
\hline Pakistan & 1999 & $1,593.5$ & $13.3 \%$ & yes & 1 & 0.3 \\
\hline Panama & 1985 & 929.5 & $12.0 \%$ & no & 0 & - \\
\hline Panama & 1994 & 562.9 & $15.1 \%$ & no & 0 & - \\
\hline Panama & 1996 & $4,715.6$ & $34.9 \%$ & yes & 2 & 34.4 \\
\hline Paraguay & 1993 & 25.4 & $29.2 \%$ & yes & 1 & - \\
\hline Peru & 1980 & 704.0 & $-4.6 \%$ & no & 0 & - \\
\hline Peru & 1983 & 651.9 & $6.3 \%$ & no & 0 & - \\
\hline Peru & 1997 & $12,485.8$ & $63.9 \%$ & yes & 13 & 31.9 \\
\hline Philippines & 1986 & $5,101.8$ & $42.6 \%$ & no & 0 & - \\
\hline Philippines & 1987 & $14,869.1$ & $15.4 \%$ & no & 0 & - \\
\hline Philippines & 1990 & $2,917.5$ & $42.8 \%$ & no & 0 & - \\
\hline Philippines & 1992 & $5,822.0$ & $25.4 \%$ & no & 0 & - \\
\hline Poland & 1982 & $7,457.5$ & $51.7 \%$ & no & 0 & - \\
\hline
\end{tabular}


Table 6: Case list: Litigation across sovereign debt restructurings (continued)

\begin{tabular}{|c|c|c|c|c|c|c|}
\hline Country & Year* & $\begin{array}{r}\text { Restructured debt* } \\
(\text { USD m) }\end{array}$ & Haircut* ${ }^{*}$ & Litigation & No. cases & $\begin{array}{r}\text { Litigation volume } \\
\text { (USD m) }\end{array}$ \\
\hline Poland & 1983 & $2,044.9$ & $52.5 \%$ & no & 0 & -1 \\
\hline Poland & 1984 & $2,302.8$ & $26.9 \%$ & no & 0 & . \\
\hline Poland & 1986 & $3,100.1$ & $37.5 \%$ & no & 0 & - \\
\hline Poland & 1988 & $12,514.4$ & $24.4 \%$ & no & 0 & - \\
\hline Poland & 1989 & 294.0 & $12.0 \%$ & no & 0 & . \\
\hline Poland & 1994 & $16,851.4$ & $49.0 \%$ & yes & 1 & 4.5 \\
\hline Romania & 1982 & $2,849.6$ & $32.9 \%$ & no & 0 & - \\
\hline Romania & 1983 & 972.7 & $31.7 \%$ & no & 0 & - \\
\hline Romania & 1986 & $1,258.9$ & $12.3 \%$ & no & 0 & . \\
\hline Russian Federation & 1997 & $35,926.2$ & $26.2 \%$ & no & 0 & - \\
\hline Russian Federation & 1999 & $5,667.3$ & $46.0 \%$ & no & 0 & . \\
\hline Russian Federation & 2000 & $37,350.9$ & $51.2 \%$ & no & 0 & . \\
\hline Sao Tome and Principe & 1994 & 12.5 & $90.0 \%$ & no & 0 & - \\
\hline Senegal & 1984 & 127.6 & $28.8 \%$ & no & 0 & - \\
\hline Senegal & 1985 & 32.1 & $31.3 \%$ & no & 0 & . \\
\hline Senegal & 1990 & 50.9 & $35.7 \%$ & no & 0 & . \\
\hline Senegal & 1996 & 95.8 & $92.0 \%$ & no & 0 & . \\
\hline Serbia & 1983 & $1,629.8$ & $6.5 \%$ & no & 0 & . \\
\hline Serbia & 1984 & $2,070.9$ & $-7.5 \%$ & no & 0 & - \\
\hline Serbia & 1985 & $5,779.4$ & $14.5 \%$ & no & 0 & . \\
\hline Serbia & 1988 & $10,222.3$ & $19.7 \%$ & no & 0 & - \\
\hline Serbia & 2004 & $2,786.6$ & $70.9 \%$ & no & 0 & . \\
\hline Seychelles & 2010 & 290.8 & $56.2 \%$ & no & 0 & . \\
\hline Sierra Leone & 1995 & 286.7 & $88.6 \%$ & no & 0 & - \\
\hline Slovenia & 1996 & 990.6 & $3.3 \%$ & no & 0 & . \\
\hline South Africa & 1987 & $16,725.8$ & $8.5 \%$ & no & 0 & - \\
\hline South Africa & 1989 & $10,703.1$ & $12.7 \%$ & no & 0 & - \\
\hline South Africa & 1993 & $6,359.5$ & $22.0 \%$ & no & 0 & - \\
\hline Sudan & 1985 & $1,477.0$ & $54.6 \%$ & no & 0 & - \\
\hline Tanzania & 2004 & 161.0 & $88.0 \%$ & no & 0 & . \\
\hline Togo & 1988 & 72.6 & $46.0 \%$ & no & 0 & - \\
\hline Togo & 1997 & 88.3 & $92.3 \%$ & no & 0 & . \\
\hline Trinidad and Tobago & 1989 & 636.5 & $15.5 \%$ & no & 0 & - \\
\hline Turkey & 1979 & $6,090.6$ & $20.9 \%$ & no & 0 & . \\
\hline Turkey & 1981 & 189.4 & $8.6 \%$ & no & 0 & - \\
\hline Turkey & 1982 & $4,046.2$ & $17.0 \%$ & no & 0 & . \\
\hline Uganda & 1993 & 194.6 & $88.0 \%$ & no & 0 & - \\
\hline Ukraine & 1998 & 616.4 & $13.3 \%$ & no & 0 & . \\
\hline Ukraine & 1999 & 187.3 & $-8.3 \%$ & no & 0 & . \\
\hline Ukraine & 2000 & $1,795.1$ & $18.0 \%$ & no & 0 & - \\
\hline Uruguay & 1983 & 986.4 & $0.7 \%$ & no & 0 & 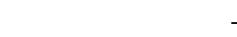 \\
\hline Uruguay & 1986 & $3,081.2$ & $24.3 \%$ & no & 0 & - \\
\hline Uruguay & 1988 & $2,624.2$ & $20.3 \%$ & no & 0 & . \\
\hline Uruguay & 1991 & $2,144.3$ & $26.3 \%$ & no & 0 & - \\
\hline Uruguay & 2003 & $3,315.8$ & $9.8 \%$ & no & 0 & . \\
\hline Venezuela, RB & 1986 & $31,956.0$ & $9.9 \%$ & no & 0 & . \\
\hline Venezuela, RB & 1987 & $30,152.6$ & $4.3 \%$ & no & 0 & - \\
\hline Venezuela, RB & 1990 & $26,952.2$ & $36.7 \%$ & no & 0 & . \\
\hline Vietnam & 1997 & 921.1 & $52.0 \%$ & yes & 1 & 1.8 \\
\hline Yemen, Rep. & 2001 & 666.6 & $97.0 \%$ & yes & 1 & 9.0 \\
\hline Zambia & 1994 & 709.9 & $89.0 \%$ & yes & 3 & 76.6 \\
\hline
\end{tabular}




\section{Comparative statics}

The following section derives the comparative statics guiding the hypotheses. Note that since $\Phi=F\left(c_{i}^{*}\left(p, h_{e}, \delta, d\right)\right)$, we can use the shorter notation $\frac{\partial \Phi}{d \delta}=\frac{\partial \Phi}{\partial c_{i}^{*}} \frac{\partial c_{i}^{*}}{\partial \delta}=\varphi d$. Thus equation (6) gives the first-order condition of the government's optimization problem in a debt restructuring as

$$
\Gamma \equiv \frac{\partial V^{R}}{\partial \delta}=D\left[\varphi d\left(1-h-p-c_{g}\right)+(1-\Phi)\right]-\kappa^{\prime}(\delta)
$$

First, we show that the government chooses a discretionary haircut $\delta$ which maximizes its payoff of the restructuring $V^{R}$. To see this, consider the second derivative of $V^{R}$ with respect to $\delta$ :

$$
\frac{\partial \Gamma}{\partial \delta}=D\left[\varphi^{\prime} d^{2}\left(1-h-p-c_{g}\right)-2 \varphi d\right]-\kappa^{\prime \prime}(\delta)
$$

where $\varphi^{\prime}=\partial \varphi / \partial c_{i}^{*}$. Eq. (A2) is negative if

$$
-c_{g}-2 \frac{\varphi}{\varphi^{\prime} d}-\frac{\kappa^{\prime \prime}(\delta)}{\varphi^{\prime} d^{2} D}<p-(1-h)
$$

The left-hand side of (A3) is clearly negative since $c_{g}>0$, the probability density function $\varphi>0$ by definition, and we have assumed $\varphi^{\prime}>0$ in order to represent a creditor distribution with an increasing mass of creditors with high costs of litigation. The right-hand side of (A3) is positive in all cases where a litigating creditor exists (see eq. 3). Hence, (A3) ensures that the haircut $\delta$ chosen by the government which solves the value function (A1) is the haircut which maximizes the government's payoff.

Lemma 1 (Hypothesis 1) The equilibrium share of litigating creditors is increasing in the probability of success $p$.

Proof To see the effect of a change in the success probability on the share of litigating creditors, we need to take into account both the direct effect on the creditors' decision, as well as the indirect effect through the government adjusting its optimal haircut. We start with deriving the indirect effect. First, take the derivative of (A1) with respect to $p$,

$$
\frac{\partial \Gamma}{\partial p}=D\left[\varphi^{\prime} d^{2}\left(1-h-p-c_{g}\right)-2 \varphi d\right]
$$

Since $\bigcirc$ value function (A1) must be zero at the optimal haircut, and we have established that (A3) is negative, we can apply the implicit function theorem to get

$$
\frac{\partial \delta}{\partial p}=-\frac{D\left(\varphi^{\prime} d^{2}\left(1-h-p-c_{g}\right)-2 \varphi d\right)}{D\left(\varphi^{\prime} d^{2}\left(1-h-p-c_{g}\right)-2 \varphi d\right)-\kappa^{\prime \prime}(\delta)}
$$

Because the common term in the numerator and denominator is negative and $\kappa^{\prime \prime}(\delta)>0$, we have $-1<\frac{\partial \delta}{\partial p}<0$. This means that the government will react to an increase in the success probability with decreasing the haircut in order to induce less creditors to hold out. But the reaction will be somewhat inelastic, such that the change in the success probability is not completely offset through the haircut. 
To see the impact of a change in the probability of success on the litigation rate, we can therefore look at its total derivative:

$$
\begin{aligned}
\frac{d \Phi}{d p} & =\frac{\partial \Phi}{\partial c_{i}^{*}} \frac{d c_{i}^{*}}{d p} \\
& =\varphi\left(\frac{\partial c_{i}^{*}}{\partial p}+\frac{\partial c_{i}^{*}}{\partial \delta} \frac{\partial \delta}{\partial p}\right) \\
& =\varphi d\left(1+\frac{\partial \delta}{\partial p}\right)>0
\end{aligned}
$$

where the sum in brackets is positive but less than 1 . The implication is that the government will stem against an increase in the litigation rate by lowering the haircut, but will not completely offset this effect due to the additional costs which the haircut implies.

Lemma 2 (Hypothesis 2a) The equilibrium share of litigating creditors is increasing in the exogenous haircut $h_{e}$.

Proof The derivation is analogous to Hypothesis 1. An increase in the exogenous haircut will have a direct effect on the creditors' decision, increasing the litigation rate; but the government will counter this to some extent by lowering the endogenous part of the haircut. First, see that

$$
\frac{\partial \Gamma}{\partial h_{e}}=D\left[\varphi^{\prime} d^{2}\left(1-h-p-c_{g}\right)-2 \varphi d\right]
$$

which can be combined with (A2) to get the indirect effect

$$
\frac{\partial \delta}{\partial h_{e}}=-\frac{D\left(\varphi^{\prime} d^{2}\left(1-h-p-c_{g}\right)-2 \varphi d\right)}{D\left(\varphi^{\prime} d^{2}\left(1-h-p-c_{g}\right)-2 \varphi d\right)-\kappa^{\prime \prime}(\delta)}
$$

The total derivative of $\Phi$ for a change in the exogenous haircut is thus positive:

$$
\frac{d \Phi}{d h_{e}}=\varphi d\left(1+\frac{\partial \delta}{\partial h_{e}}\right)
$$

again, because the elasticity of the endogenous haircut is less than 1 .

Lemma 3 (Hypothesis $\mathbf{2 b )}$ The equilibrium share of litigating creditors can increase in the restructured debt volume.

Proof The derivation is analogous to Hypothesis 1 and 2a. The total derivative of $\Phi$ for a change in the debt volume is:

$$
\begin{aligned}
\frac{d \Phi}{d D} & =\frac{\partial \Phi}{\partial c_{i}^{*}} \frac{d c_{i}^{*}}{d D} \\
& =\varphi\left(\frac{p-(1-h)}{n}+d \frac{\partial \delta}{\partial D}\right)
\end{aligned}
$$

The elasticity of the haircut with respect to a larger debt volume is negative, meaning the government will choose a smaller loss if the restructured debt is high. This is due to the fact that we assume a fixed cost of litigation for creditors, and hence an increase in the debt volume will make litigation relatively more profitable by allowing greater leverage. Hence, the direct effect of a greater debt volume (first term in brackets) is positive, and 
the second term is negative. Under a positive relationship between the debt volume and the share of litigating creditors, $\partial \delta / \partial D>\frac{1-h-p}{D}$ must be true.

First, the derivative of (A1) with respect to $D$ is given by

$$
\frac{\partial \Gamma}{\partial D}=\left(1-h-p-c_{g}\right)\left[2 \varphi d+\varphi^{\prime} d^{2}(p-1+h)\right]+1-\Phi-\varphi d(p-1+h)
$$

Hence the condition for the total effect to be positive can be expressed as

$$
\begin{aligned}
\frac{\partial \Gamma}{\partial D} & >\frac{p-1+h}{D} \frac{\partial \Gamma}{\partial \delta} \\
(p-1+h) \frac{\kappa^{\prime \prime}(\delta)}{D}+1-\Phi & >\left(p-1+h+2 c_{g}\right) \varphi d
\end{aligned}
$$

Since both sides are positive, the direction of the effect will depend on the other parameter values. In the empirical part, we therefore consider interaction effects between the main variables and the debt size.

Lemma 4 (Hypothesis 3) : The equilibrium share of creditors can decrease in the upper bound of creditor litigation costs.

Proof The elasticity of the haircut to changes in creditor cost distribution is given by:

$$
\frac{\partial \delta}{\partial \bar{c}}=-\frac{D\left(\frac{\partial \varphi}{\partial \bar{c}} d\left(1-h-p-c_{g}\right)-\frac{\partial \Phi}{\partial \bar{c}}\right)}{D\left(\varphi^{\prime} d^{2}\left(1-h-p-c_{g}\right)-2 \varphi d\right)-\kappa^{\prime \prime}(\delta)}
$$

Since $\frac{\partial \varphi}{\partial \bar{c}}>0$ and $\frac{\partial \Phi}{\partial \bar{c}}>0$, the elasticity of the haircut with respect to an increase in the upper bound of the creditor cost distribution is positive. If creditor costs increase, the government will choose a higher discretionary haircut, anticipating that it will lead to a smaller share of litigating creditors. To see the total effect, we need to combine this indirect effect with the direct effect:

$$
\begin{aligned}
\frac{d \Phi}{d \bar{c}} & =\frac{\partial \Phi}{\partial \bar{c}}+\frac{\partial \Phi}{\partial c_{i}^{*}}\left(\frac{\partial c_{i}^{*}}{\partial \bar{c}}+\frac{\partial c_{i}^{*}}{\partial \delta} \frac{\partial \delta}{\partial \bar{c}}\right) \\
& =\frac{\partial \Phi}{\partial \bar{c}}+\varphi d \frac{\partial \delta}{\partial \bar{c}}
\end{aligned}
$$

Plugging in (A13) and rearranging, we see that there exist solutions where the total derivative is negative as long as:

$$
\frac{\partial \Phi}{\partial \bar{c}}<\frac{D \frac{\partial \varphi}{\partial \bar{c}} d^{2} \varphi\left(1-h-p-c_{g}\right)}{D \varphi^{\prime} d^{2}\left(1-h-p-c_{g}\right)-\kappa^{\prime \prime}(\delta)-\varphi d(2 D-1)}
$$

If (A15) holds depends on the other parameters' values. But in the limit for the debt volume increasing, the right hand side of the equation will approach a negative constant, making the statement true for large debt volumes. In the empirical section, we therefore interact the creditor cost variable with the debt volume. 